\title{
Global Governance and the WTO
}

\author{
Andrew T. Guzman*
}

\section{INTRODUCTION}

Since 1947 the General Agreement on Tariffs and Trade (GATT) and its successor, the World Trade Organization (WTO), have brought about a dramatic reduction in barriers to international trade. The WTO has become one of the world's most dominant international institutions, established a reasonably effective system of dispute resolution, and developed a nearly universal membership. These achievements, however, have not protected the organization from external criticism or internal challenges.

Indeed, the remarkable success of the GATT/WTO system is, to a significant degree, responsible for the challenges now facing the WTO. Over time, and especially as a result of the Uruguay Round, the GATT/WTO has moved from a system of rules prohibiting trade measures to a system of rules requiring affirmative government actions. ${ }^{1}$ The consequence is a WTO engaged in monitoring and adjudicating the legality of domestic rules that are not primarily or exclusively about trade. ${ }^{2}$ The relevant WTO obligations include rules governing the protection of intellectual property, service industries, and health and safety measures. ${ }^{3}$ Though each of these WTO rules, with the possible exception of the Agreement on Trade-Related Aspects of Intellectual Property Rights ("TRIPs Agreement"), ${ }^{4}$ has an important con-

* Professor of Law, Boalt Hall School of Law, University of California at Berkeley. Ph.D., Harvard University, 1996; J.D., Harvard Law School, 1996; B.Sc., University of Toronto, 1990. I owe thanks to Jeff Arik, Stephen Choi, Jeffrey Dunoff, Larry Helfer, Robert Howse, Brad Karkkainen, Richard Steinberg, Chantal Thomas, Michael Trebilcock, participants at the International Trade Roundtable held at Boalt Hall in January 2003, and faculty workshop participants at Boalt Hall School of Law, Harvard Law School, and the University of Toronto Law School for helpful comments. Special thanks to Daniel Frederick and Nicholas James. Jennie Wang and Ryan Waterman provided outstanding research assistance.

1. See Sylvia Ostry, WTO: Institutional Design for Better Governance, in EFFICIENCY, EQUITY AND LEgitimacy: The Multilateral Trading System at the Millennium 361, 363-64 (Roger B. Porter et al. eds., 2001).

2. See, e.g., Panel Report, United States-Section 110(5) of the US Copyright Aat, WT/DS160/R (June 15, 2000) (dealing with copyright issues); Appellate Body Report, United States-Import Probibition of Certain Sbrimp and Sbrimp Products, WT/DS58/AB/R (Oct. 12, 1998) (dealing with environmental issues) [hereinafter Shrimp/Turtle]; Appellate Body Report, European Communities-Measures Concerning Meat and Meat Products (Hormones), WT/DS26/AB/R (Jan. 16, 1998) (dealing with health and safety issues).

3. See Claude E. Barfield, Free Trade, Sovereignty, Democracy: The Future of the World Trade Organization, 2 CHI. J. INT'L L. 403, 406 (2001).

4. Agreement on Trade-Related Aspects of Intellectual Property Rights, Including Trade in Counterfeit Goods, art. 27.1, Apr. 15, 1994, Marrakesh Agreement Establishing the World Trade Organization, Anṇex 1C, Legal Instruments-Results of the Uruguay 
nection to liberalized trade, their substance makes it impossible to consider them in strictly trade terms.

The impact of the trading regime is also felt in areas that are not subject to any specific WTO regulation. For example, environmental policy, human rights, labor, and competition policy are not directly within the jurisdiction of the WTO, but in each of these areas trade and the trading system have influenced policymaking. The influence of WTO obligations on non-trade issues has generated cries of protest from many quarters. Critics argue that the WTO remains a trade institution at heart, and that its forays into what were traditionally considered non-trade areas have caused the non-trade values at stake to be ignored in favor of trade concerns. ${ }^{5}$ Thus, the argument goes, the tremendous power of the organization, combined with its efforts to influence policies in non-trade areas, has elevated trade at the expense of other issues.

The dramatic failure of the WTO's 1999 Ministerial Conference in Seattle demonstrated the dissatisfaction of certain groups with the current state of globalization. Protesters succeeded in drawing attention to their concerns about labor, environmental, and human rights issues. ${ }^{6}$ The collapse of the Seatrle Ministerial stands as dramatic evidence that international cooperation and globalization is unlikely to continue with a focus on trade alone. ${ }^{7}$ Nor is this view limited to those outside the organization. WTO members appear to have recognized that they must address concerns other than those directly linked to trade. ${ }^{8}$ At the Doha Ministerial in Novermber 2001, the WTO laid out an agenda for the Doha Development Round that allows for a discussion of some of these non-trade issues, including environment, competition policy, and investment. ${ }^{9}$ Extending the reach of the WTO into non-trade areas, however, will clearly not be easy, as was demonstrated when the Cancun

Round, 33 I.L.M. 81, 93 (1994) [hereinafter TRIPS AGREEMENT].

5. See, e.g., Margaret Graham Tebo, Power Back to the People, 86 A.B.A. J. 52, 54 (July 2000) ("Shortly before the [WTO's meeting, Sherrod Brown, member of the U.S. House of Representatives] said it was important to "make labor standards, environmental standards and human righrs as important to our trade bureaucrats as incellectual property rights." ).

6. See Mark Weisbrot, One Year After Seattle: Globalization Revisited, Center for Economic and Policy Research, (Nov. 27, 2000), available at http:/www.cepr.net/wto/seattleplusonefinal.htm (last visited May 1, 2004) (providing an opponent's view of the events at Seattle).

7. Cf. Barfield, supra note 3, at 404-05.

8. See, e.g., Helene Cooper et al., Up in Smoke: WTO's Failure in Bid to Launch Trade Talks Emboldens Protestors, Wall. ST. J., Dec. 6, 1999, at Al (discussing the resistance of developing countries to the incorporarion of labor srandards in WTO agreements).

9. See World Trade Organization, Ministerial Declaration of 14 November 2001, WT/MIN(01)/DEC/ 1, 41 I.L.M. 746 (2002) [hereinafter Doha Declaration]. Among the issues to be negotiated in the new round are investment, environment, and competition policy. The opening provided by the Doha Development Round should not be exaggerated, however. For example, the Doha Declaration states that the Committee on Trade and Environment should investigate only certain environmental issues and their relationship to trade, especially "the effect of environmental measures on market access." Id. If 32 . This is well short of a commitment to bring environmental issues within the WTO in a manner analogous to intellectual property. Similarly, the WTO is moving into the field of compecition policy in gingerly fashion, with the Doha Declaration calling on the Working Group on the Interaction of Trade and Competition Policy to focus only on "core principles, including transparency, non-discrimination and procedural fairness, and provisions on hardcore cartels; [and] modalicies for voluntary cooperation." Id. ๆ 25. 
Ministerial in September 2003 ended in failure, in part due to disagreement on the question of what to do about investment and competition policy, and in part because of an inability to make progress on agricultural issues. ${ }^{10}$

These developments have placed the WTO and the international economic community at a crossroads. The status quo is unsustainable because, although the influence of the WTO now extends well beyond the trade arena, the institution remains overwhelmingly oriented toward trade concerns. Critics are right to point out that non-trade issues are largely overlooked at the WTO, and yet, the organization cannot avoid environmental, labor, or other issues. The dispute resolution organs of the WTO have already addressed cases on the environment, for example, and more such cases are likely to be filed in the future. ${ }^{11}$ Labor and human rights cases are also easy to imagine. Though such cases would focus on trade disputes (for example, the permissibility of economic sanctions in response to certain labor rights practices) there is no denying that they would also implicate important non-trade issues. This interaction between trade and non-trade issues will only grow stronger over time, and the pressure to address the conflicting priorities that result will continue to rise. The WTO, therefore, must eventually either move forward by finding a way to incorporate more regulatory issues within its mandate or move backward and retreat to a narrower focus on trade, leaving controversial topics such as the environment outside of its influence.

Though there are many hurdles to the incorporation of new issues into the WTO, the alternative of reduced international economic cooperation is inconsistent with the needs of an increasingly global economy. ${ }^{12}$ Turning away from non-trade issues does not make them go away, nor does it change the fact that the trade and non-trade issues are connected. Rather it pushes these issues into the shadows and prevents policy formation from occurring in an open and organized fashion. ${ }^{13}$ Using the WTO as an institution devoted exclusively to trade is also unrealistic. The GATT/WTO system has never been constrained so narrowly, and it is probably impossible to construct a system so constrained. As John Jackson has pointed out, effective international trade measures will always have some impact within national borders. ${ }^{14}$

10. See Kevin Sullivan, Ricb-Poor Trigger Collapse of the Trade Talks, WaSH. Post, Sept. 15, 2003, at A1.

11. See Shrimp/Turtle, supra note 2.

12. See Marco C. E. J. Bronckers, More Power to the WTO?, 4 J. INT'L ECON. L. 41, 41 (2001) (“[M] and more issues can no longer be resolved domestically—and, if domestic measures are taken, they easily create conflicts with other jurisdictions.").

13. See Daniel C. Esty, Bridging the Trade-Environment Divide, 15 J. Econ. Persp. 113, 114 (2001) ("The only choice [with regard to trade and the environment] is whether the policies put in place to respond will be designed openly, explicitly, and thoughtfully, with an eye to economic and political logic -or implicitly and without systematic attention to the demands of good policy-making.").

14. See John H. Jackson, The Perils Of Globalization and the World Trading System, 24 Forduam INT'L L.J. 371,374 (2000):

[Slome people in the United States have argued that we should reverse course and take the WTO back to the time when ir was responsible only for border measures, thereby limiting its ability to 
The better strategy, then, is to bring non-trade topics into the debate at the WTO. The power of the WTO has already caused its reach to extend into non-trade related issues such as health and safety, intellectual property, and the environment. The non-trade interests in these areas are sufficiently powerful and important that they must be given a voice if relevant trade rules are to be sustained. Failure to grant such a voice would only amplify criticism of the WTO and weaken its ability to manage cooperation.

The non-trade concerns at issue-sometimes referred to as "trade and . .." issues ${ }^{15}$ or "fair trade" issues ${ }^{16}$ —include (ar least for the purposes of this Article) human rights, environmental issues, ${ }^{17}$ labor, ${ }^{18}$ investment, competition policy, ${ }^{19}$ and intellectual property. ${ }^{20}$ Among the consequences of the trade bias said to exist within the WTO is the frustration of efforts to use trade sanctions as a tool to change the policies of foreign states with respect to these issues. ${ }^{21}$

Much of the criticism leveled at the WTO stems from the perception that the liberalization of international trade has received inappropriate prominence, and that other values have been sacrificed as a result. ${ }^{22}$ One solution to this perceived problem-the one usually at the center of the discussionis to slow or stop the expansion of the WTO into non-trade areas. ${ }^{23} \mathrm{An}$ alternative solution-one that is more consistent with the reality of growing

affect national regulation internally. This is folly, because such time never existed. It was always recognized that there were measures in GATT that would have effects behind the border.

15. See Joel P. Trachtman, Institutional Linkage: Transcending "Trade and ...", 96 AM. J. INT'L L. 77 (2002).

16. See Fair Trade and Harmonization: Prerequisites for Free Trade? (Jagdish Bhagwati \& Robert E. Hudec eds., 1996).

17. The most active literature has been in the environmental area. See generally DaniEL C. ESTY, Greening the GatT: Trade, Environment, and the Future (1994); Thomas J. Schoenbaum, International Trade and Protection of the Environment: The Continuing Search for Reconciliation, 91 AM. J. INT'L L. 268 (1997).

18. See generally Raj Bhala, Clarifying the Trade-Labor Link, 37 Colum. J. Transnat'L L. 11 (1998); Andrew T. Guzman, Trade, Labor, Legitimacy, 91 CAL. L. REv. 885 (2003); Robert Howse, The World Trade Organization and the Protection of Workers' Rights, 3 J. SMALL \& EMERgING Bus. L. 131 (1999); Virginia A. Leary, Workers' Rights and International Trade: The Social Clause (GATT, ILO, NAFTA, U.S. Laws), in 2 Trade and Harmonization: Prerequisites for Free Trade? 177 (Jagdish Bhagwari \& Robert E. Hudec eds., 1996).

19. See generally Eleanor Fox, International Antitrust and the Doba Dome, 43 VA. J. INT'L L. 911 (2003); Andrew T. Guzman, Is International Antitrust Possible?, 73 N.Y.U. L. Rev. 1501 (1998).

20. See generally Jeffrey L. Dunoff, The Death of the Trade Regime, 10 EUR. J. INT'L L. 733, 739-45 (1999) (discussing several "trade and ..." issues, including environment, labor, competition, intellectual property, investment, and culture). The list presented here is not exhaustive but is sufficient for the purposes of the proposal advanced herein. Other topics might be added to the list, but I leave to another time a discussion of the merits of any other particular issues.

21. See Tebo, supra note 5 , at 52 ("By making decisions that favor free trade over concerns about people and the environment, the activists say, the WTO is thwarting efforts to press for change through economic sanctions directed at countries that allow such abuses within their borders.").

22. See Robert Howse \& Makau Mutua, Protecting Human Rights in a Global Economy: Challenges for the World Trade Organization 11 (2000) ("Institutionally, the GaT'T developed in isolation, a fact which produced a single-minded free trade perspective.").

23. See, e.g., John O. McGinnis \& Mark L. Movsesian, The World Trade Constitution, 114 Harv. L. Rev. 511,514 . 
international activity-consists of increasing the level of global cooperation and focusing on important non-trade issues. That is, rather than slowing progress in the trade area, non-trade concerns should be addressed by increasing the level of international cooperation and promoting agreements that take both trade and non-trade issues into account. ${ }^{24}$

At first glance, the idea of moving toward more, rather than less, global governance may seem inconsistent with the objections voiced by WTO opponents. As one examines these complaints carefully, however, it becomes clear that only increased global cooperation can provide an effective strategy for addressing their concerns. Like WTO supporters, critics recognize that international cooperation is needed to address the challenges of globalization. ${ }^{25} \mathrm{~A}$ turn away from the institution, then, is an odd prescription.

This Article proposes that the WTO should, over time, expand its role to include non-trade issues. Doing so will require changes to the institution, and this Article outlines the necessary reforms. This is not the first proposal suggesting an expansion of the WTO, ${ }^{26}$ but it offers a novel set of reforms that retain the benefits of a stable, influential, and effective international organization while mitigating the institution's trade bias. Though a reformed WTO will not be perfect, the alternatives - the most prominent being the establishment of stand-alone issue-oriented institutions ${ }^{27}$-are far worse.

This Article recommends that the WTO be structured along departmental lines to permit its expansion into new areas while taming its trade bias. A department for each major issue area would be created within the institution-a trade in goods department, a trade-in-services department, an intellectual property department, an environmental department, and so on ${ }^{28}$ Each department would hold periodic negotiating rounds to which member states would send representatives. These "Departmental Rounds," however, would be limited to issues relevant to the organizing department. Members could take

24. This call for greater cooperation should not be mistaken for an argument in favor of any particular form of cooperation. It is beyond the scope of this Article to examine the substantive terms on which states should inceract. This Article is focused on process, offering a way for states to address important international issues in an effective and coherent fashion. Once such a process is in place, there obviously will remain a host of important substantive questions.

25. See, e.g., Moisés Naím, Lori's War, Foreign Pol'y, Spring 2000, at 28, 37-47 (interviewing Lori Wallach, Director of the Public Citizen's Global Trade Watch).

26. See, e.g., I.M. Drestler \& Peter J. Balint, The New Politics of American Trade: Trade, LABOR, AND THE ENVIRONMENT 39-66 (1999); Bronckers, supra note 12. For a glimpse of the other side of this debate, see, for example, Jagdish Bhagwati, Afterword: The Question of Linkage, 96 AM. J. INT'L L. 126 (2002); Daniel K. Tarullo, Norms and Institutions in Global Competition Policy, 94 AM. J. INT'L L. 478 (2000).

27. See, e.g., EsTY, supra note 17, at 73-98 (proposing a free standing "Global Environmental Organization"); Eleanor M. Fox, Competition Law and the Millennium Round, 2 J. INT'L ECON. L. 665 (1999) (proposing a free standing "World Competition Forum").

28. To some extent this resembles the existing Council for TRIPs, Council for Trade, and Council for Trade in Services. In other respects, the proposed departments might resemble the existing committees and working groups within the WTO, such as the Commitcee on Trade and Environment, the Working Group on Competition Policy, and the Working Group on Investment. In any case, the departments would enjoy greater autonomy and authority than the existing Councils. 
advantage of the more specialized, streamlined Departmental Rounds to reach agreement on issues that do not implicate other departments. ${ }^{29}$ In addition to the Departmental Rounds, there would be periodic "Mega-Rounds" of negotiation that would cover issues from more than one department. ${ }^{30}$ Mega-Rounds allow two different types of trade-offs across departmental lines. First, they permit agreements that implicate more than one department, such as an environmental agreement that includes a set of trade-based enforcement provisions. Second, they open the door to agreements in one departmental area that are possible only if concessions are made in another departmental area, as was the case with the TRIPs Agreement and, as I have argued elsewhere, would be necessary for an agreement on comperition policy or labor. ${ }^{31}$ MegaRounds are roughly analogous to the current practice of negotiating rounds, including the ongoing Doha Round and the earlier Uruguay Round where the TRIPs Agreement was negotiated. ${ }^{32}$

Despite dramatic differences in perspective, both proponents and critics of the WTO agree that some form of international cooperation to address nontrade concerns is required. That these groups with opposing agendas should agree is not surprising. Any serious consideration of topics such as the environment, intellectual property, and health and safery measures eventually must address their substantial international implications. One cannot speak for long about environmental issues, for example, before international concerns such as greenhouse gases arise. Regardless of how one feels about the appropriate balance between the environment and economic growth, it is clear that global environmental concerns can be addressed more effectively through cooperative efforts among states. That sort of balance and cooperation cannot be achieved by a retreat from globalization, and specialized international

29. The establishment of Departmental Rounds, then, represents an improvement over the existing negotiation structure because it introduces a forum in which a relatively narrow set of issues can be discussed and agreement can be achieved. At present, amendments to the WTO agreements may only be done at a Ministerial. See Final Act Embodying the Results of the Uruguay Round of Multilateral Trade Negotiations, art. X, Apr. 15, 1994, Legal Instruments-Results of the UruGUAY Round vol. 1 (1994), 33 I.L.M. 1125 (1994) [hereinafter FINAL ACT]. Ministerials take place every two years and allow members to discuss all marters under any of the multilateral trade agreements. See id. art. IV: 1 .

30. In principle a Mega-Round could include all issues of relevance to the organization. More realistically, WTO members would limit the range of issues to be discussed in the same way they do with WTO negotiating rounds today, i.e., they would have preliminary discussions to set out a work program for negotiations. See Doha Declaration, supra note 9. Though the work program may be changed as the negotiarions proceed, as happened during the Uruguay Round negotiations, it helps members to focus on a common set of questions.

31. See Andrew T. Guzman, Essay: Antitrust and International Regulatory Federalism, 76 N.Y.U. L. REv. 1142 (2001); Guzman, supra note 19; Guzman, supra note 18.

32. A fair description of the TRIPs Agreement includes recognizing that the intellectual property goals of developed states were achieved in exchange for concessions to developing countries on market access issues. See Frederick M. Abbott, Commentary: The International Intellectual Property Order Enters the 21st Century, 29 VAND. J. Transnat'L L. 471,472 (1996) [hereinafter Abbott, International Intellectual Property]; Frederick M. Abbott, The New Global Tecbnology Regime: The WTO TRIPs Agreement and Global Economic Development, 72 CHI.-KENT L. REv. 385, 387-88 (1996) [hereinafter Abbott, New Global Technology Regime]. 
organizations are not equipped to promote the necessary dialogue. The better answer is to leverage the WTO's existing success by reforming the institution and turning it into a "World Economic Organization." 33

\section{A BETTER WTO}

As international integration proceeds, economic and regulatory challenges continue to mount. Scholars and practitioners addressing issues of international cooperation have not overlooked these challenges. The most commonly advocated solution is the establishemnt of issue-oriented international institutions. ${ }^{34}$ Such calls have been heard in the environmental, ${ }^{35}$ labor, ${ }^{36}$ and competition policy literature. ${ }^{37}$ Others have suggested that dispute resolution panels at the WTO should apply certain non-WTO norms more aggressively and should take international commitments made outside the WTO into account when evaluating state conduct. ${ }^{38}$

This Article proposes a different approach to the problem of international governance in an age of interdependence. Rather than establishing separate international institutions with the inevitable start-up costs and uncertaintynot to mention the problem of how these institutions will interact with one another-the international community should take advantage of the WTO's strength by expanding its jurisdiction to include additional substantive issues. That expansion, of course, generates attendant challenges and risks and requires reform of the institution to ensure that future international negotiations take place efficiently and that the new organization does not place trade interests ahead of other concerns. Some of the more systemic questions are addressed below. Other concerns are discussed in detail in Part IV.

A problem that must be considered at the outset is the increased complexity generated by an expansion of the WTO's jurisdiction. Everything from the day-to-day operation of the institution to the organization and execution of future negotiating rounds to dispute resolution would become more difficult to manage. First, incorporating additional issues would complicate

33. This name is borrowed from Bronckers, supra note 12, at 64. For the sake of clarity, this Article will refer to this organization as the WTO.

34. See, e.g., Steve Charnovitz, A World Environment Organization, 27 Colum. J. ENvTL. L. 323 (2002); Daniel C. Esty, The Value of Creating a Global Environmental Organization, ENv'T MATTERS, June 2000, at 13.

35. Among those who have suggested a World Environmental Organization is former WTO DirectorGeneral Renato Ruggiero: "It will not be possible if we are just talking abour trade liberalization. We need to have real progress towards environmental legislation, with the creation of a World Environmental Organization." Larry Elliot, The World on bis Shoulders, Guardian, Apr. 30, 1999, at 24.

36. Renato Ruggiero suggested that "[w]e also need progress in the International Labour Organisation in defence of social values such as labour standards and child protection." $1 d$. at 24 .

37. See Fox, supra note 27.

38. See Joost Pauwelyn, Conflict of Norms in Public international Law: How WTO Law Relates to Other Rules of International Law 456-72 (2003); Robert Howse \& Kalypso Nicolaidis, Legitimacy and Global Governance: Why Constitutionalizing the WTO is a Step Too Far, in EFFICIENCY, Equity and Legitimacy: The Multilateral Trading System at the Millennium 227 (Roger B. Porter et al. eds., 2001). 
the negotiations that take place at the WTO. Rather than focusing primarily on trade, as is currently the case, an expanded WTO also would have to consider, for example, environmental and labor issues. Second, an expansion of WTO authority may threaten the benefits of specialization and expertise that have served the organization well over its history. Bringing disparate topics together in a single organization, then, could make the regulation of each of them less effective.

Fortunately, the problems of increased complexity and reduced specialization can be addressed through the departmental structure proposed in this Article. One of the important responsibilities of the departments would be to manage periodic departmental negotiating rounds addressing issues within their respective issue areas. Any agreements emerging from these Departmental Rounds would generate WTO obligations for member states. ${ }^{39}$ The use of Departmental Rounds is an important element of the proposal because, without them, negotiation at the WTO might become hopelessly complex. An increase in the number of topics within the WTO's jurisdiction increases the set of potential deals, the number of negotiators, and the number of relevant interests at stake..$^{40}$ At best, attempting to conduct all negotiations simultaneously would be inefficient. At worst, it might be paralyzing.

Departmental Rounds would eliminate the need to address every issue through this sort of all-at-once negotiation. Agreements reached within a Departmental Round would be restricted in scope to the subject matter within the department's jurisdiction. Though such a constraint limits the range of agreements that can be negotiated, there is every. reason to think that many valuable agreements can nevertheless be achieved. In fact, virtually all international negotiations on regulatory matters undertaken to date, whether inside or outside the WTO, have addressed only a single issue area, often with positive results. For example, the various trade rounds at the WTO have focused al-

39. One might reasonably be concerned that a proliferation of departments would tax the already scarce capacity of many developing countries to participate in decision making. This is a legitimate concern and one that requires careful consideration. Though I do not have a solution to the problem of capacity, it seems that the creation of departments within the WTO cannot make the problem worse and might actually generate a small improvement. Whether non-trade issues are discussed within WTO departments or elsewhere, developing countries face the same capacity constraints. If they are housed within the WTO, there is at least some potential for states to marshal what resources they have more effectively. For example, a country with .concerns about both trade and the environment but with limited capacity could have a single representative participate in borh the trade and environment departments. If environmental issues are discussed in an ad hoc negotiation or within a stand-alone environmental organization, it may be impossible for this single individual to participate in both. The problem might simply be geographical-negotiations or other organizations may be in a different part of the world; or it may be institutional-it is hard enough to learn the culrure of a single organization and the presence of two separate organizations will make it even harder for a single representative to participate in both. There are significant and obvious disadvantages to having a single person work in two areas at once, and this proposal does not eliminate those disadvantages. The only claim here is that the creation of departments does not aggravate this serious problem.

40. Notice that with an increase in the number of issues there would be a geometric increase in the number of potential agreements, because each final agreement represents a delicate balancing of interests and concessions across many issues. 
most exclusively on trade, ${ }^{41}$ environmental negotiations (conducted outside the WTO) are typically limited to environmental issues, and competition policy talks have been similarly constrained. ${ }^{42}$

Negotiations within departments would allow states to reach agreements at a lower cost than would negotiations that include all departments. They would allow issue area specialists to carry out the relevant negotiation within the department without the risk that, for example, the environmental department will approve a set of measures that include trade restrictions without full consideration of relevant trade concerns. ${ }^{43}$

Because individual departments would not be permitted to establish obligations that go beyond their departmental authority, they will neither be able to commit states to obligations that significantly affect other departments, nor structure concessions in one department to generate agreement in another. Negotiations of that sort are reserved for the Mega-Rounds, where any number of departments may be involved. ${ }^{44}$ The range of potential issues would be broader in scope than any current form of international negotiation at the WTO or elsewhere, opening the door to a richer set of potential cooperative agreements. ${ }^{45}$

Skeptics might point out that periodic rounds of negotiation have proven difficult when a more limired set of topics has been considered. Certainly, the failed Cancun Ministerial is evidence of this fact. Presumably, agreement would be even more challenging if topics such as environmental law, competition policy, and labor were also included-making the Mega-Rounds unwieldy, perhaps to the point of paralysis. This is a legitimate concern, but rather than illustrate a problem with wide-ranging rounds, it demonstates their

41. One exception is the negotiation of the TRIPs Agreement during the Uruguay Round.

42. See Guzman, supra note 31 .

43. One might ask how the borders of the departments will be policed to prevent over-reaching by a department that generates conflict with another department. Fortunately the borders at issue would be self-enforcing. Because each department would include representacion from every member state, and because unanimity is required for an agreement, any encroachment by one department into the jurisdiction of another would draw the attention of the member states who are well-placed to mediate such conflicts both between their own representatives and amongst themselves. In the example given in the text, an individual member state would recognize that the agreement had a trade dimension when its environmental representative proposed the agreement to her superiors. At that point, the member state would have every reason to consult with its trade specialists-effectively bringing the trade department into the discussion and preventing a departmental agreement on the issue. Knowing all of this would happen, the environmental representatives would limic their departmental negotiations to environmental issues. Notice also that the existing borders of the WTO itself operate in exactly this way. The WTO does not move easily into new substantive areas because member states monitor the behavior of their representatives. The problem is also greatly reduced by the fact that, as discussed infra in Part IV.B.2, there is no bureaucratic apparatus within the departments with the authority to generate rules. There is, accordingly, no cause for concern about bureaucratic expansion of departmental borders.

44. As mentioned previously, the first step in a Mega-Round likely would be to identify issues to discuss and set an agenda for the talks. See supra note 30.

45. One could hypothesize the use of some other international institution as the home for cross-issue area tradeoffs, of course. It is hard to imagine what existing organization could succeed in this role, however, and given the importance of trade in any cross-issue area negotiations it is much more sensible to work within a reformed WTO. 
importance. With only trade on the table, other concerns are ignored. This not only leads to agreements that favor trade concerns over other issues, but it also prevents non-trade concerns from being considered at all. The result, then, is a set of agreements with a trade bias and an absence of agreements in other related areas. Though the proposed Mega-Rounds would be difficult, they would be made easier by the presence of Departmental Rounds. Complexity is an inevitable result of trying to tackle the difficult problem of how to balance competing interests at a global level.

Regardless of where agreements are reached-whether at the Departmental Rounds or a Mega-Round-the resulting commitments would become part of a state's WTO obligations. As such, they would be subject to the dispure resolution provisions of the Dispute Setrlement Understanding (DSU), unless states specified otherwise in their agreement. ${ }^{46}$ The dispute resolution system would remain outside the control of any single department. This would require some reform of existing procedures, but the general character of dispute resolution would remain the same. Detailed discussion of the proposed reforms of the DSU and the reasoning behind them is left for later in the Article. ${ }^{47}$

The new WTO, then, would consist of: a series of departments, each of which would hold its own negoriations; periodic Mega-Rounds of negotiation; and a dispute settlement system that is charged with the task of resolving disputes within the organization. From one perspective, this proposal is not all that far removed from existing proposals for strengthening or creating stand-alone organizations devoted to specific issue areas. Creating a labor or environmental department retains the advantages of a stand-alone organization but offers the additional benefits of cross-issue area transfers and the strength of the DSU. For this reason, the proposal dominates calls for separate stand-alone organizations.

Before proceeding, a word about the political prospects for reform is in order. There is no denying that the reforms suggested in this Article are substantial and go beyond what is currently being considered at the Doha negotiations. The proposal, however, is not as radical as it may first appear. The inclusion of non-trade issues is certainly not unprecedented, as intellectual property is already handled in the WTO. Other non-trade issues are knocking at the door, with discussion of competition and environmental issues formally included on the Doha Agenda. What is being considered in these issue areas is admittedly more modest than what is proposed in this Article, but it is significant that the continued pressure to address non-trade issues is generating a response from the WTO. Furthermore, the way in which nego-

46. See Understanding on Rules and Procedures Governing the Settlement of Disputes, art. 2, Apr. 15, 1994, Marrakesh Agreement Establishing the World Trade Organization, ANNEX 2, Legal INSTRUMENTS-RESUlTS OF THE URuguay Round, 33 I.L.M. 112 (1994) [hereinafter DSU].

47. See infra Part III.C. 
tiations already take place at Ministerials features a fair amount of compartmentalization. During the Cancun Ministerial, for example, negotiations were divided into five groups, which discussed, first, agriculture; second, development; third, non-agricultural market access; fourth, the "Singapore issues" of competition policy, investment, trade facilitation, and government transparency; and fifth, a miscellaneous group for other issues. The proposal is also something that should be adopted over a period of time to allow the organization to adapt. Thus, for example, an initial step would be to create departments for issues already handled at the WTO, e.g., trade in goods, trade-in-services, and intellectual property. ${ }^{48}$ Additional issues could be brought in over time.

Finally, even if this proposal is not accepted, there remains value in its normative approach. Whether the WTO ever adopts the departmental structure outlined in this Article or not, it is useful to recognize that these reforms could resolve many significant problems for the organization. In addition, the Article points out why stand-alone institutions designed to deal with issues such as labor and the environment-the main alternative to incorporation of these topics within the WTO-represents a poor solution.

\section{The Merit of Global Governance at the WTO}

This Article's proposal rests on an analysis of two questions. First, should a single institution be charged with a range of regulatory issues, including environment, labor, competition, human rights, and trade? Second, assuming an affirmative answer to the first question, what organization should take on that responsibility? This Part advances the case in favor of housing a range of international economic issues within a single institution. It then demonstrates why a reformed WTO should be the starting point for the construction of that single institution. Part IV addresses potential concerns with the proposal.

\section{A. Eliminating the Trade Bias}

One of the most salient critiques of the WTO is that it places trade values ahead of other concerns, including the environment, human rights, and labor. ${ }^{49}$ The prioritization of trade issues is not surprising in light of the fact that the WTO is a trade organization, staffed by trade specialists, and guided by agreements negotiated with an eye toward the trading regime. To be fair, it may not be accurate to say that the problem stems from the WTO's focus on trade issues. Rather, the problem exists because the organization is rela-

48. The precise set of departments may well differ from this and include, for example, an agriculture group.

49. The WTO panels' consideration (or lack thereof) of environmental issues are the most commonly cited examples of this problem. See Sbrimp/Turtle, supra note 2. For a discussion of Shrimp/Turtle, see Arthur E. Appleton, Sbrimp/Turtle: Untangling the Nets, 2 J. INT'L EcoN. L. 477 (1999). 
tively powerful and effective. If, for example, an environmental organization were in place that enjoyed similar influence and success, there might be less concern about the WTO. In the absence of such an environmental organization, however, there is a perception that trade interests trump environmental interests.

What is missing, then, is a way to counter the WTO's trade interests with appropriate environmental interests, labor rights interests, etc., without undermining the strengths of the trading system. One common proposal is to build stronger specialized non-trade institutions such as a "World Environmental Organization" or a more effective International Labor Organization (ILO)..$^{50}$ Although creating such entities would not reduce the trade bias of the WTO, the notion presumably is that these organizations would have their own biases and the various international institutions would keep one another in check.

Growth in the number of institutions, however, has significant dangers. First, there is no guarantee that new organizations could be established with universal membership. Developing countries have no reason to join a powerful labor organization that might force them to improve local standards to the detriment of their economic well-being. ${ }^{51}$ Similarly, an effective international environmental organization may have little to offer developing states who are often prepared to accept lower environmental standards in exchange for economic growth. Membership in a Global Environmental Organization would also be reduced because non-members could free-ride on the environmental protections required of member states. ${ }^{52}$ Getting the consent of all or even most states for such organizations, then, may not be possible. Without universal membership there is no reason to think these institutions will prosper and be able to check the influence of the WTO.

Second, even if one could establish a universal organization dedicated to, for example, environmental concerns, it may never achieve the success and influence of the WTO. In fact, the ILO is an example of such an organiza-

50. See supra notes $34-36$.

51. The fact that the ILO has many developing country members does not imply that a stronger ILO would be welcome. In fact, the inability of the ILO to get consensus on more stringent substantive standards or effective enforcement suggests that many members are unwilling to go along with such proposals. Why, then, would they join a stronger ILO that has those features?

52. Within the WTO such free-riding would not be possible because environmental commitments would bind all members. Another, less severe free-rider problem would remain, however, as each state would try to get the organization to adopt environmental obligations whose costs are felt by other states. This problem is similar to the free-rider problem faced in WTO trade calks that use bilateral commitments coupled with the Most-Favored-Nation principle as their foundation. This negotiating structure gives a state an incentive to make no commitments of its own while benefiting from those made by others. In practice, this problem has not proved fatal because members have adopted a principle of reciprocity under which states are expected to give concessions that are comparable to those they gain. Though difficult to measure, this norm has reduced the free-rider problem. In recent rounds, the WTO has also used a tariff-cutring formula, requiring that tariffs be cut across the board. This, too, reduces the freerider problem (though some items are inevicably excepted from the across-the-board cuts). There is no reason that similar solutions cannot be adopted in non-trade areas such as the environment. 
tion with respect to labor issues. Despite having a large membership and being the recognized center for cooperation on such issues, the ILO remains much less powerful than the WTO. ${ }^{53}$

Third, if the ILO became more powerful, and if an influential international environmental organization came into being, it is not clear that the mere existence of such institutions would lead to a desirable balance among trade, environment, and labor concerns. New issue-oriented organizations bring attention to the relevant issues, but do little to address the more important question of how conflicting priorities should be managed. How should the trade goals of the WTO be reconciled with the environmental priorities of a World Environmental Organization? How should conflicts between these organizations be resolved? Stand-alone organizations are unable to answer these questions and would, therefore, leave many international regulatory problems unaddressed. By incorporating a range of issues into a single institution, it would be possible for negotiators, appointed by national governments, to get down to the critical business of balancing the benefits of trade against the values of other issues such as the environment or labor. ${ }^{54}$

For all of these reasons, establishing separate, stand-alone organizations is less promising than the incorporation of the relevant issue areas within a single organization. The question then arises: what is the appropriate organization? Should a new one be created from scratch, or would it be better to adapt an existing institution to the needs of the international community?

The case for using a reformed WTO to house these issues is powerful. The WTO has already established itself as a strong and effective institution with a good record of state compliance. Furthermore, it has incorporated at least one non-trade issue: intellectual property. 55 Its strength and its demonstrated ability to incorporate additional issues are evidence in favor of an

53. See, e.g., Chantell Taylor, NAFTA, GATT, and the Current Free Trade System: A Dangerous Double Standard For Workers' Rights, 28 Denv. J. INT'L L. \& Pol'y 401, 423 (2000) ('While the [ILO] Conventions espouse seemingly industrious labor stands, in fact the principles are meaningless without a concomitant enforcement mechanism."). The difficulty in creating an international institution whose strength rivals that of the WTO is evidenced by the fact that the WTO stands alone as the most effective and powerful such organization.

[T] he World Trade Organization (WTO) is the envy of international lawyers who are more familiar with less efficient and more compliance-resistant legal regimes, including those within the International Labor Organization, United Nations (UN) human rights bodies, and other adjudicative arrangements such as the World Court or the ad hoc war crimes tribunals.

Jose E. Alvarez, How Not to Link: Institutional Conundrums of an Expanded Trade Regime, 7 WIDENER L. SYMP. J. 1, 1 (2001).

54. See Bronckers, supra note 12, at 54 ("Negotiators ... would then weigh the merits of these public policies against the benefirs of liberal trade. This would be preferable to litigators arguing over important public policies as exceptions to [trade agreements].").

55. The incorporation of intellectual property has not been without controversy. As is so often the case with international cooperation, progress has been difficult and contentious. That said, whatever the flaws in the WTO's treatment of intellectual property, I am not aware of anyone that claims the WTO's trade bias has led to an agreement that privileges trade over the protection of intellectual property. Rather, the TRIPs Agreement has generated controversy precisely because of the way in which it raises barriers to trade. See John D. Blum, The Role of Law in Global E-Health: A Tool for Development and Equity in a Digitally Divided World, 46 ST. Louis U. L.J. 85, 103-04 (2002). 
expansion of the WTO. With appropriate adjustments to the WTO, it would be possible to take advantage of the institutional strength of the organization to avoid or overcome the challenges facing stand-alone institutions, and at the same time limit the reformed organization's trade bias. Restructuring the WTO as a set of departments, as discussed in Part IV.A.1, would separate the reformed organization from its trade roots enough to provide a fair hearing for other important values. Trade would not disappear as a priority, but it would share the stage with other issues.

\section{B. Managing Conflicting Priorities}

The nature of international regulation often makes it unrealistic to expect international cooperation in non-trade areas without some form of linkage. International agreements in areas such as competition policy, labor, and environment are much more likely when states are able to make concessions that cross issue areas. Separating the negotiation of trade from non-trade issues, and separating non-trade issues from one another, handicaps negotiation and is likely to frustrate agreements that could make all states better off. This leads to the straightforward but nevertheless underappreciated point that a forum should exist in which issues are grouped together at the negotiation stage to allow for suitable cross-issue transfers.

One of the many challenges facing international cooperation in areas such as the environment, human rights, labor, intellectual property, and competition policy is that states have divergent interests. States may disagree because they have different tastes and priorities, but they may also disagree because states with different economies and trade flows will have conflicting goals. The clearest example is in the area of intellectual property. Developed states have every reason to support a strong intellectual property regime because the vast majority of innovation takes place in those countries. In fact, in the presence of trade, the preferred international regime for a country that exports intellectual property is actually more protective of intellectual property rights than would be the case in an otherwise identical closed economy (i.e., one withour international trade). ${ }^{56}$ An open economy that exports intellectual property puts more weight on the benefits of future innovation than does a closed economy, and puts less weight on the reduced consumer access to the technology. This is because the state does not care about consumers that are located abroad. Thus, some of the costs of stricter intellectual property rules are felt by foreigners, and these costs are ignored when the innovating country considers its preferred policy. Moreover, all of the increased profits that go to innovators as a result of greater protection of intellectual property are enjoyed by the innovating country, so those gains are included in the policy calculus. The innovating country, therefore, prefers

56. See Andrew T. Guzman, International Antitrust and the WTO: The Lesson from Intellectual Property, 43 VA. J. INT'L L. 933, 947 (2003). 
stronger protection for intellectual property if it is an exporter of intellectual property than if it is a closed economy.

On the other side of trade in intellectual property are, of course, importers. They do not receive any of the benefits of increased profits when intellectual property protections are increased, ${ }^{57}$ but they do suffer when their citizens are unable to gain low-cost access to the property. These importing states will, therefore, prefer an international policy with relatively weak intellectual property protections. ${ }^{58}$

As long as there are net importers and net exporters of intellectual property, this divergence will exist. Note that the positions of the states result from their respective trade flows in intellectual property, and not a lack of communication, differences of opinion with respect to the economics of intellectual property, or idiosyncratic preferences.

Because underlying economic interests cause states to have inconsistent policy preferences, any agreement changing the existing level of international intellectual property protection will benefit some states and hurt others. ${ }^{59}$ Unless they are compensated in some way, states that would be harmed by an agreement will refuse to consent to it. In principle, compensation could take any number of forms-from cash to concessions in another area of international relations. For that compensation to be offered and accepted, however, negotiators must be authorized to bargain over more than just intellectual property. Discussing intellectual property in a specialized forum such as the World Intellectual Property Organization (WIPO) is unlikely to lead to an agreement because negotiators cannot offer concessions in other areas.

Embedding negotiation of intellectual property in an organization that also oversees negotiation on other topics, however, opens the door to an exchange of concessions across issue areas. Indeed, this is what happened with intellectual property. Many prior attempts to negotiate an agreement through WIPO failed, but once the WTO took up the issue, an agreement was struck in which developing countries were offered compensation in the form of concessions relating to agricultural subsidies, market access for agricultural goods, and protection against unilateral sanctions by developed countries, especially the United States. ${ }^{60}$ These concessions simply could not have been negotiated through WIPO. ${ }^{61}$

57. Although they would get some future benefit if greater protections led to an increase in the rate of innovation.

58. See Guzman, supra note 56 , at 947.

59. This is a slight overstatement because a move toward a more desirable international intellectual property regime would generate a net gain that may or may not lead to a welfare gain for every state.

60. See Abbott, International Intellectual Property, supra note 32, at 472; Abbott, New Global Technology Regime, supra note 32 , at 388.

61. See Guzman, supra note 56, at 950-51 ("The decision to place the negotiations within the Uruguay Round, therefore, proved critical. Had IP negotiations remained within WIPO, negotiators would have been unable to exchange IP concessions by developing countries for trade concessions by developed countries."). 
Strategic problems of this sort are also present in other non-trade areas. In competition policy, developed countries are home to the bulk of firms that operate in imperfectly competitive industries (where antitrust is an issue), and so they favor relatively weak international antitrust protections. Developing states, on the other hand, have reason to favor relatively strong protections since their consumers benefit from increased competition. ${ }^{62}$ As with intellectual property, an international agreement on antitrust seems unlikely unless the negotiations provide for transfer payments. Though there is support in the competition policy literature for a single, stand-alone forum for the negotiation of international antitrust, ${ }^{63}$ that literature does not explain how the forum could overcome the divergent interests of states. I have argued elsewhere that the WTO is the most promising forum for arranging the necessary transfers among states. ${ }^{64}$

Similar analyses could be applied to environmental and labor issues. For example, an effort to reduce deforestation is likely to be very costly to Brazil, but to benefit many other states. In this example, Brazil has no incentive to accept a globally desirable policy because it bears a disproportionate share of the costs. If other states want such a policy, however, it may be possible to obrain it by offering Brazil concessions in other areas. They may offer concessions in other environmental areas (e.g., other states could commit to tougher emissions policies), but there is even greater opportunity for cooperation if concessions can come in other forms. For example, Brazil might be prepared to join an agreement on deforestation in exchange for trade concessions.

With respect to labor, developing countries have concerns that international labor standards will reduce the competitiveness of their labor-intensive industries. Based on these concerns, developing states have an incentive to resist many international labor agreements. ${ }^{65}$ Again, if these agreements are desirable from a global perspective, it may be possible to achieve them through the use of concessions in unrelated areas. For example, a particular labor rights

62. These preferences relate to the level of international enforcement that would be preferred by the states if there were a single, harmonized global policy. It offers an explanation for why the United States has consistently resisted calls for international harmonization while developing states have expressed an interest in such cooperation. This is not to be confused with the fact that developing countries have relatively weak domestic antitrust laws in comparison to the United States. This is to be expected because small open economies that cannot or do not apply their laws extraterritorially have no incentive to adopt competition laws that restrict the actions of domestic firms without affecting the behavior of foreign firms that sell to local consumers. A large country like the United States that applies its laws extraterritorially, on the other hand, has an incentive to adopt competition laws both because a substantial percentage of local production is also consumed locally (causing it to internalize the benefits of antitrust laws) and because extraterritorial application of its laws imposes the costs of strict antitrust rules on foreign firms while delivering the benefits to local consumers.

63. See Fox, supra note 27 , at 665.

64. See Guzman, supra note 31; Guzman, supra note 19.

65. See Bhagwati, supra note 26 , at 133. 
agreement might be acceptable to developing states if developed states agree to reduce agricultural subsidies. ${ }^{66}$

In general, then, an expanded WTO offers a promising forum in which to negotiate agreements on topics that require concessions to be made across issue areas. ${ }^{67}$ Each of the issue areas discussed in this Article would benefit if transfers could be structured to make agreement on value-increasing deals possible. Furthermore, as each issue area is brought into the WTO, it will become a potential source of concessions when agreement is sought in other areas, further increasing the choice set for negotiators. Thus, for example, developing countries might receive an agreement on international competition policy in exchange for concessions relating to labor. Expanding the set of issues within the organization expands the number of potential deals. Though such cross-issue negotiations can be cumbersome, they can also lead to agreements that could not otherwise be achieved. ${ }^{68}$

The importance of dispute resolution is discussed in the next Part of this Article, but a brief note is appropriate here. Once one recognizes that negotiation over international trade and regulatory issues involves concessions and trade-offs by all states, one should also recognize that enforcement issues are sure to be a problem. In many instances of international cooperation, compliance can be secured through the credible threats of the parties to end their own compliance in response to a violation. Thus, for example, a treaty banning nuclear weapons testing may succeed in preventing such tests because both parties are better off with mutual compliance than with mutual violation.

Where an agreement is achieved through concessions in unrelated areas, however, there is a greater need for effective dispute resolution and enforcement. Suppose, for example, that Venezuela enters into a treaty that requires compliance with certain environmental standards. Assume that these standards are higher than what Venezuela would desire as a global standard and, in fact, Venezuela would prefer the status quo to this agreement except for the fact that it received some other benefit-for example, greater market access-in exchange for its consent. Though Venezula's international law obligation may, by itself, cause it to comply with the agreement, a dispute resolu-

66. But see Howard Chang, Carrots, Sticks, and International Externalities, 17 INT'L REv. L. \& ECoN. 309,314 (1997) (discussing strategic issues relating to international agreements, and pointing out that states may adopt bad policies in an attempt to extract concessions).

67. See Bronckers, supra note 12, at 45 ("[It is] possible within the WTO to break deadlocks where other organizations have failed, because here governments can make package deals."); Michael Moore, The WTO and the Arab World: Preparations for Doba, Address at the UNCTAD High-Level Meeting for Arab Countries (June 20,2001), available at http://www.wto.org/english/news_e/spmm_e/spmm65_e.htm (last visited May 1, 2004) ("There is a much greater chance of reducing agricultural support in Europe and Japan if other countries are willing to make concessions in areas where Europe and Japan have demands, such as competition, investment, and anti-dumping."); Jeffrey Atik, Democratizing the WTO, 33 Geo. WASH. INT'L L. REV. 451 (2001).

68. See Claude Barfield, Free Trade, Sovereignty, Democracy: The Future of the World Trade Organization 38 (2001) ("The most productive and fruitful legislative advances in the WTO are undoubtedly a result of the package deals put together at the end of periodic trade rounds."). 
tion mechanism makes this outcome more likely. The threat that other states may also refuse to comply with the higher environmental standards will not generate compliance because, by assumption, Venezuela prefers a regime without the treaty.

Nor is the alternative of withdrawing compliance with whatever concessions were given in exchange for Venezuela's agreement a workable solution because the precise quantum of concessions made by one country for a particular concession by another is rarely known even by the negotiators of a complex agreement. ${ }^{69}$ Other states could, of course, react with sanctions of some form. This creates at least three problems. The first is that the sanctions may be excessive-without any limiting principle, the offended country may overreact out of anger, miscalculation, or to appease domestic political constituents. Second, the open-ended potential for sanctions may generate bad faith claims of violation. If, for example, the steel lobby is pressing hard for protection, the government may declare a violation in an unrelated area in order to justify what would otherwise be an illegal protectionist measure. Finally, withour some focal point for sancrions-such as withdrawal of one's own compliance on the same issue-states may disagree on the facts related to an alleged violation and the resulting sanction. Each side may claim that the other is in violation, leading to a tit-for-tat exchange of sanctions and potentially a trade war.

To make sanctions effective, then, it is helpful to have some established dispute settlement procedures. Though this Arricle certainly does not advance the claim that the dispute settlement procedures of the WTO are perfect, they remain the most effective existing form of dispute settlement that can be applied to such commitments. Dispute settlement makes commitments more credible which, in turn, increases the ability of states to make welfare-increasing deals. At the same time, dispute settlement protects against excessive or unjustified sanctions. The benefits of dispute resolution may not outweigh its costs in all cases, of course. With this in mind, this Article proposes that dispute resolution be a default rule.

The above benefits of linkage stand apart from another form of linkage that is sometimes discussed. This latter use of the term refers to the application of trade sanctions for a failure to comply with non-trade rules. There is significant disagreement about whether trade should be used in this way, and if so, how the relationship should be managed. ${ }^{70}$ Those who support this sort of linkage should also support the inclusion of relevant issue areas within the WTO. The only way that proper tradeoffs can be established and

69. It is, for example, impossible to know what specific concessions were made in exchange for agreement on the General Agreement on Trade in Services (GATS). The problem is even more vexing if we are concerned with a particular provision within the agreement.

70. See Gary C. Hufbauer et al., Economic Sanctions Reconsidered: History And Current Policy (2d ed. 1990); Howse, supra note 18, at 158; Alan O. Sykes, International Trade and Human Rights: An Economic Perspective (May 2003), available at http://www.law.uchicago.edu/Lawecon/WkngPprs_176200/188.aos.human-rights.pdf (last visited May 1, 2004). 
effective exceptions to WTO trade rules can be put in place is through the incorporation of other issue areas.

\section{Dispute Resolution}

\section{Extending the Benefits of Dispute Resolution}

Commitments in areas such as the environment, labor, and human rights face significant enforcement problems. As discussed above, the risk that other states will withdraw their own compliance will often be inadequate to generate compliance. The international community lacks coercive enforcement structures analogous to those found in domestic systems, so optimal levels of compliance may simply not be attainable. Nevertheless, compliance can be improved with the establishment of institutions capable of identifying and publicizing violations. Though simply monitoring and drawing attention to violations, as is done by many international organizations, including the ILO, can encourage compliance, more powerful strategies are available. ${ }^{71}$

The international community has some experience with the use of tribunals to identify violations of international law. The most effective dispute resolution procedures are found within the WTO. ${ }^{72}$ The merits and demerits of the WTO's dispute settlement procedures are well documented, and it serves no purpose to review them here. ${ }^{73}$ Though the existing system is certainly not perfect, it is enough to observe that the procedural rules-strong by the standards of international organizations-set within a mandatory dispute settlement system has produced a mechanism that is the envy of other international institutions. ${ }^{74}$ Making this dispute settlement system available beyond the trade area would greatly improve the credibility of commitments made in those areas, and would, therefore, open the door to a wider set of commitments.

Given the substantial advantage of the WTO over other dispute resolution bodies and the importance of mandatory dispute resolution to the credibility of commitments, ${ }^{75}$ there is a strong case for making a dispute resolution body with similar characteristics available to negotiators in a range of regulatory areas. In principle, of course, one could imagine constructing separate dispute settlement procedures to deal with non-trade issues such as environmental law. In practice, however, there is no guarantee that the international community could reproduce the success of the DSU. If anything, the uniqueness of the DSU suggests that effective dispute resolution bodies are not so easily built.

71. See Andrew T. Guzman, International Law: A Compliance Based Theory, 90 CAL. L. REv. 1823 (2002).

72. See Bronckers, supra note 12 , at 45 .

73. See Alan Wm. Wolff, Problems with WTO Dispute Settlement, 2 CHI. J. INT'L. L. 417 (2001).

74. See Bronckers, supra note 12 , ar 45 .

75. See Andrew T. Guzman, The Cost of Credibility: Explaining Resistance to Inter-State Dispute Resolution Mechanisms, 31 J. LeGaL STUd. 303 (2002). 
Bringing non-trade topics within the WTO, then, would give states access to the organization's dispute settlement procedures and increase the credibility of commitments and the level of compliance. This would generate two critical benefits. First, as discussed above, it would provide effective dispute resolution in non-trade areas-something that may not be possible through any other strategy. Second, because trade and non-trade issues are related, the obligations taken on in one area may sometimes generate disputes that implicate issues in other areas. Establishing a uniform adjudicatory system within the jurisdiction of the DSU will avoid the problem of multiple fora that open the door to forum shopping and competition among the various dispute settlement entities. It is easy to imagine, for example, one of the parties to a dispute turning to the trade forum while the other party turns to the environmental forum. With no higher court available to resolve such conflicts there would be no way to avoid or resolve this sort of uncoordinated and unpredictable dispute resolution.

Explicit extension of WTO authority would also help clarify existing uncertainty about how conflicts between the WTO and other international agreements should be resolved. This issue is most salient in the environmental area, where it is well-known that obligations under multilateral environmental agreements have the potential to generate trade-related conflicts. ${ }^{76}$ This risk has been increased by the large number of environmental agreements signed in the last thirty years and the use of trade sanctions as an enforcement tool in many of those agreements. ${ }^{77}$

Conflicts between dispute resolution at the WTO and elsewhere are already a subject of concern. ${ }^{78}$ The WTO Secretariat suggests that the WTO should defer to other dispute resolution procedures, including those in an environmental agreement. ${ }^{79}$ The WTO website, for example, states that:

The Trade and Environment Committee says that if a dispute arises over a trade action taken under an environmental agreement, and if both sides to the dispute have signed that agreement, then they should try to use the environmental agreement to settle the dispute. But if one side in the dispure has not signed the environment agreement, then the WTO would provide the only possible forum for settling the dispute. That does not mean environmental issues would be ignored. The WTO agree-

76. See Montréal Protocol on Substances that Deplete the Ozone Layer, Sept. 16, 1987, S. Treaty Doc. No. 100-10, 1522 U.N.T.S. 3.

Convention on International Trade in Endangered Species of Wild Fauna and Flora, Mar. 3, 1973, 27 U.S.T. 1087, 993 U.N.T.S. 243.

77. See Barfield, supra note 3, at 405.

78. See Atik, supra note 67, at 457-58; Paul B. Stephan, The New International Law-Legitimacy, Accountability, Authority, and Freedom in the New Global Order, 70 U. CoLo. L. Rev. 1555, 1559-60 (1999).

79. See Thomas Schoenbaum, WTO Dispute Settlement: Praise and Suggestions for Reform, 47 INT'L \& CoMP. L.Q. 647, 652-53 (1998). 
ments allow panels examining a dispute to seek expert advice on environmental issues. ${ }^{80}$

Other observers believe that the dispute settlement panels within the WTO should look to non-WTO international law only sparingly. ${ }^{81}$ Furthermore, the Secretariat's quote above is inconsistent with Article 23 of the DSU, which makes the WTO procedures the exclusive forum for dealing with violations of WTO obligations. ${ }^{82}$ Bringing environmental issues within the WTO would ensure that there is a single forum within which to resolve such conflicts. As future agreements are reached, an expanded WTO could also provide the drafters of such agreements with the opportunity to anticipate and provide for the interaction of trade and environmental issues in a way that is currently impossible. ${ }^{83}$

None of this is to suggest that the creation of an effective dispute settlement system outside the trade area is simple. Though the general structure of the dispute settlement system could remain the same, some particulars would have to be adjusted. Most obviously, the ability to suspend concessions if a losing party fails to comply with the ruling of a panel or the Appellate Body might have to be elaborated to suit new issue areas. ${ }^{84}$ As long as the relevant obligations concern trade measures, the existing procedures would continue to work. If, however, members were to take on non-trade obligations that themselves were subject to dispute resolution, new rules would be needed to determine the appropriate level of suspension of concessions. Whether some form of sanction is permitted unilaterally (analogously to what is currently permitted in anti-dumping, for example) ${ }^{85}$ or if alleged violations must be addressed through the DSU, the permissible forms of retaliation, sanction, or withdrawal of concessions must be established. The level of sanctions is, of course, closely related to the substance of the obligations in question and, therefore, must be negotiated contemporaneously. Just as this Article does not propose any particular agreement on non-trade topics, it does not take a position on the best response to violations of such an

80. Understanding the WTO: Cross-Cutting and New Issues: The Environment: A New High Profile, available at http://www.wto.org/english/thewto_e/whatis_e/tif_e/bey2_e.htm. (last visited May 1, 2004).

81. See Joel P. Trachtman, The Domain of WTO Dispute Resolution, 40 Harv. INT'I. L.J. 333, 343 (1999).

82. See DSU art. 23.1; Trachtman, supra note 81, at 366.

83. There remain questions about the extension of the jurisdiction of the DSU. The Article returns to the issue and addresses such questions infra in Part IV.B.3.

84. A complainant can request authority to suspend concessions or other obligations if the losing party fails to comply with the recommendations of the panel or Appellate Body within a reasonable time and if negotiations over mutually acceptable compensation are not successful. See DSU art. 22.1.

85. See General Agreement on Tariffs and Trade, art. VI, Oct. 30, 1947, 61 Stat. A-11, 55 U.N.T.S. 194 [hereinafter GATT]; AGREEMENT ON IMPLEMENTATION OF ARTICLE VI OF THE GENERAL agreement on Tariffs and Trade 1994, in AnNex 1 A to the Agreement Establishing the World Trade Organization, Final ACt, supra note 29, reprinted in World Trade Organization, The Legal Texts: The Results of the Uruguay Round of Multilateral Trade Negotiations 147 [hereinafter ANTI-DumpING AGREEMENT]. 
agreement. The goal here is simply to structure the organization so that value-increasing agreements are more likely.

\section{Which Obligations Get Dispute Resolution?}

Expanding the WTO would also raise difficult questions about the proper treatment of the many existing non-WTO international obligations, the most obvious of which are the significant environmental, human rights, and labor agreements. For example, if environmental issues are brought within the WTO, should existing environmental obligations also come within the WTO's jurisdiction and, if so, should they be subject to the dispute settlement system? Because many such obligations exist, and because states accepred them on the understanding that they would be outside the WTO, it seems both simpler and more consistent with the intent of the parties to leave these agreements as non-WTO obligations (and outside the scope of the DSU). Of course, existing obligations could be imported into the WTO system if the parties consented.

There is no reason to give the expanded WTO a monopoly on international cooperation, so it does not seem troubling to leave these agreements outside the organization-especially for those agreements that are thought to be working well on their own. Nor does there seem to be any significant reason to resist the incorporation of the obligations into the WTO system. Bringing an agreement within the WTO would not change the obligations of states, so if there are practical reasons to have an obligation within the WTO, there is little reason to object.

There is also the question of whether dispute resolution should apply to all WTO obligations negotiated in the future. If dispute resolution is required, it may reduce the willingness of states to enter into commitments. If it is not required, the credibility of the relevant commitment is reduced. ${ }^{86}$ In my view, WTO dispute resolution should nor be considered mandatory for all WTO agreements, and states should be free to choose whether new agreements will be subject to the organization's mandatory dispute resolution procedures. Thus, states should be permitted to make some agreements that have different dispute resolution provisions, or none at all. The dispute settlement system-one of the great strengths of the WTO-should be a default rule rather than a mandatory rule. ${ }^{87}$ The case for a default rule is even stronger if existing obligations are imported into the WTO. For these obligations, states have not consented to a dispute resolution procedure. Adding

86. I have discussed how dispute resolution affects credibility and the willingness of states to include dispute resolution provisions in some detail in prior writings. See Guzman, supra note 75; Andrew T. Guzman, The Design of International Agreements (Jan. 2004), available at hrtp://papers.ssrn.com/sol3/ papers.cfm?abstract_id $=487662$ (last visited May 1, 2004).

87. Of course, if an agreement were subject to the DSU, those provisions would be mandatory. See DSU art. 2. 
one after the fact changes the force of the agreement without the consent of the parties. ${ }^{88}$

Notice that there is no conflict between the suggestion made in this Partthat mandatory dispute resolution be a default rule-and the discussion in the last Part about the merits of mandatory dispute resolution. ${ }^{89}$ Dispute resolution should exist only as a default rule because states may prefer, when entering into agreements, to make commitments that are not subject to this form of enforcement mechanism. If such agreements are welfare-enhancing for all states, there is no reason to forbid them. That said, some agreements will only be possible if the promises exchanged are credible and dispute resolution may provide an important boost to credibility. For agreements of that sort, mandatory dispute resolution has great value. In either case, the system should allow and, indeed encourage, states to enter into agreements that make them both better off. Dispute resolution will serve that goal in many, but not all, cases.

One might be concerned that agreements without dispute resolution provisions lack force and are, therefore, not valuable. Though it is certainly true that dispute resolution improves the credibility of a commitment, it does not follow that international agreements without such provisions are meaningless. In fact, the vast majority of international agreements do not have mandatory dispute resolution provisions. Making an effective dispute resolution mechanism available but not mandatory gives states a wider range of options and, therefore, makes it more likely that they will enter into Paretoimproving agreements.

There may occasionally be tension between the desire to enter into agreements that involve cross-departmental trade-offs and the ability to opt-out of dispute resolution. Imagine, for example, an agreement in which developed countries agree to an opening of their agricultural markets in exchange for environmental commitments from developing countries. On the one hand, states may be reluctant to enter into the agreement without dispute resolution because each fears that the other will fail to comply. On the other hand, dispute resolution procedures may themselves discourage states from making a commitment. In such a case, the states will presumably fail to make a deal. Though such an outcome is possible, notice that it does not undercut the basic thrust of this Article. Allowing cross-issue area bargains and making effective dispute resolution available increases the scope for welfareimproving agreements. Even this structure, however, cannot always yield cooperation. The merit of the proposal advanced in this Article is not that it solves all problems, but rather that it is superior to the status quo or a strategy of stand-alone institutions. Not only are these alternative approaches unable to generate cooperation in the above example, they rule out virtually all

88. See infra Part IV.B.3 (explaining why panels should not consider non-WTO law).

89. See supra Part III.C.1. 
cross-issue area trade-offs and offer no dispute resolution option outside the trade area.

\section{Disincentives to Exit}

Efficient and unbiased dispute resolution can improve compliance with an international agreement in at least two different ways. First, it establishes a peaceful and objective way for states to overcome legal disagreements. Even when cooperation is mutually beneficial, a dispute may escalate if each state has a different view of the relevant obligations. Each may believe that it has acted appropriately and it is the other state that has caused the dispute. The problem can be aggravated by the fact that domestic decision makers are likely to frame a dispute in the way that maximizes their own political payoff. A dispute that grows out of this sort of informational conflict can be resolved through the use of a dispute settlement system, especially when that mechanism is mandatory. Either state can force the other into the dispute settlement process. Once a panel rules on a dispute, the informational problem is largely cured. ${ }^{90}$

Dispute resolution can also contribute to compliance by increasing the cost of violating international law. It is true that there is no coercive enforcement mechanism in place at the WTO, but a respected dispute settlement system is able to establish culpability. ${ }^{91}$ This, in turn, can increase the reputational costs of a violation as wrongdoing is brought to the attention of all member states. It also establishes a structure for the orderly and limited application of economic sanctions. Although the sanctions at the WTO are intended to be neither retrospective nor punitive, ${ }^{92}$ they do reduce the payoff to a state from an ongoing violation. As such, they reduce the incentive to commit the violation in the first place.

The above benefits could, in principle, be achieved in any agreement that includes mandatory dispute settlement procedures. ${ }^{93}$ The WTO has an additional advantage, however. The obligations imposed on a state by an agreement can be ignored by that state in two different ways. First, the state can violate the agreement, in which case it faces the sanctions described above. Alternatively, the state can abrogate the agreement. By exiting an agreement, of course, a state can avoid the relevant commitments without violating international law. Though political or reputational consequences may result, at a minimum the state avoids the dispute resolution process and permanently escapes the relevant commitments. Within a stand-alone agree-

90. The presence of a dispute settlement procedure also can discourage states from opportunistically making inaccurate claims about the actions of other states in an attempt to gain a political advantage.

91. It is a small overstatement to say that there is no coercive enforcement mechanism at the WTO. The potential for the withdrawal of concessions granted to states that fail to comply with DSU rulings is a form of coercion, although it is limited in its forcefulness.

92. See DSU art. 22.

93. This is a slight exaggeration, as a stand-alone treaty could not approve the use of trade sanctions without running afoul of the WTO. 
ment, then, a state will find it worthwhile to exit whenever the burden of its obligations outweighs the benefits. So, for example, an environmental treaty that requires a reduction in emissions will only remain in force with respect to a state as long as the agreement yields a net benefit to that state. This makes such agreements relatively fragile, as demonstrated by the decision of the United States to withdraw its support for the Kyoto Protocol. ${ }^{94}$

By comparison, states have a much more circumscribed exit option at the WTO. Imagine, for example, that developing states had agreed to the TRIPs Agreement in the form of a stand-alone agreement rather than within the auspices of the WTO. As discussed earlier, the consent of the developing states required transfers in the form of trade concessions. Once the TRIPs Agreement was in place, developing states had every reason to resist compliance as they had consented only in order to get the trade concessions. ${ }^{95}$ If TRIPs obligations were housed within a stand-alone IP organization, one would expect developing states to exit the agreement, constrained only by the political consequences of doing so.

As compared to a stand-alone agreement, exit from the WTO is much more difficult. To be sure, it remains within the sovereign power of a state to exit. ${ }^{96}$ States cannot, however, exit from a subset of the WTO agreements while remaining party to the others..$^{97}$ The decision to exit, then, would amount to a decision to leave behind a large and complex set of agreements and practices.

94. See Douglas Jehl, Hemisphere Conference Ends In Discord on Global Warming, N.Y. TIMEs, Mar. 31, 2001, at A11.

95. Predictably, a number of disputes have arisen in which developing country compliance with the TRIPs Agreement has been challenged. See, e.g., Request for Consultations by the United States, BrazilMeasures Affecting Patent Protection; WT/DS199/1 (June 8, 2000); Request for Consultations by the United States, Argentina - Certain Measures on the Protection of Patents and Test Data, WT/DS196/1 (June 6, 2000); Request for Consultations by the United States, Argentina-Patent Protection for Pharmaceuticals and Test Data Protection for Agricultural Chemicals, WT/DS171/1 (May 10, 1999); Request for Consultations by the European Communities, India-Patent Protection for Pharmaceutical and Agricultural Chemical Products, WT/DS79/1 (June 5, 1997).

96. See FINAL ACT art. XV:1 ("[W] ]ithdrawal . . shall take effect upon the expiration of six months from the date on which written notice of withdrawal is received ..."). The political discourse in the Unired States, for example, occasionally includes threats or proposals to exit the WTO.

The final recourse for the United States would be to quit the WTO, which any nation can do on six months' notice. This option was underscored last week by the Clinton-Dole agreement. Under Dole's escape-clause plan, Congress could vote to leave the WTO if the United States wound up on the losing side of three WTO decisions in a five-year period and a review panel of federal judges found that U.S. rights under the WTO agreement had been violated.

Peter Behr, Congress to Cast Vote On Historic Trade Pact; GATT's Issues Transcend Political Parties, Wash. Post, Nov. 28, 1994, at Al.

If the United States loses both cases currently before the World Trading Organization over access to Japan's auto market, subsequent U.S. political fallout could undermine the fledgling WTO and, by extension, the world trading system, said a key U.S. trade analyst in an interview Thursday. 'If there's a double loss, no one will support the WTO in the United States,' said Charles Lake, former U.S. Trade Representative official who oversaw U.S. trade policy toward Japan between 1990 and late 1994 .

Mark Magnier, US Defeat In Auto Cases Would Be Bigger Loss For WTO, Analyst Says, J. COM., June 9,1995 , at $8 \mathrm{~A}$.

97. See FinAL ACT art. XV. 
Because the WTO combines a large set of value-increasing agreements, exit from the organization is less attractive than would be exit from any stand-alone agreement. Witness how the conflict over TRIPs and pharmaceuticals was eventually resolved. Though developing countries were unhappy with their TRIPs commitments, and despite the fact that in some cases they violated those commitments, no state decided to exit the WTO to avoid its obligations under TRIPs. Ultimately, a political solution was achieved at the Doha Ministerial where the "Declaration on the TRIPs Agreement and Public Health" was issued. ${ }^{98}$ If TRIPs had been a stand-alone agreement, it is more than likely that developing states would simply have exited.

\section{Challenges for an Expanded WTO}

This Part addresses some important challenges and potential objections to the expansion of WTO authority. Many of the criticisms leveled against the WTO are well-placed. The organization is certainly imperfect and, as currently structured, is not a suitable forum for discussion of environmental, labor, and other issues. To the extent critics claim that the WTO in its current form should not incorporate non-trade issues, they are probably correct but have focused on the wrong question. Asking whether the current WTO is a suitable forum for non-trade issues does not help us to understand how the international community should manage cooperation in trade and other issues. When this latter issue is addressed, the WTO becomes an attractive institution through which to work. With appropriate reforms-some of which have already been presented, and some of which are discussed in this Partthe WTO can address the concerns of skeptics, extend its role in a productive fashion, and generate benefits for the international community.

\section{A. Institutional Competence}

\section{Changing the Organization}

Perhaps the first question that must be asked is whether the WTO has the ability, as an institution, to incorporate non-trade issues. ${ }^{99}$ If one looks at the WTO as it exists today, the answer is clearly "no." The WTO is a relatively small organization devoted to trade. ${ }^{100}$ There is not enough staff to manage a significant expansion, and it lacks expertise in areas such as environmental law and human rights. ${ }^{101}$ Simply put, the WTO and its precursor, the

98. See WTO Ministerial Conference, Declaration on the TRIPs Agreement and Public Health, WT/MIN(01)/DEC/2 (Nov. 20, 2001), 41 I.L.M. 755 (2002).

99. See EstY, supra note 17; Steve Charnovitz, Environmental Harmonization and Trade Policy in TradE and the Environment: Law, EConomics and Policy 267 (Durwood Zaelke et al. eds., 1993); Jeffrey L. Dunoff, Institutional Misfits: The GATT, The ICJ and Trade-Environment Disputes, 15 MiCH. J. INT'L L. 1042 (1994); Tarullo, supra note 26.

100. The WTO's total budger in 2003 was approximately 155 million Swiss francs (about U.S. $\$ 115$ million). WORLd Trade Organization, WTO ANNual Report 2003, at 158.

101. See J. Patrick Kelly, The WTO and Global Governance: The Case for Contractual Treaty Regimes, 7 
GATT, were built to handle trade, and are poorly equipped to deal with other issues. ${ }^{102}$

Skepticism of the WTO's ability to manage non-trade issues is often advanced as a justification for a separate, specialized institution. ${ }^{103}$ It seems, however, a failure of the imagination to think that the WTO cannot be reformed. The proposed reform of the WTO is intended to address this institutional capacity problem. By structuring the organization as a series of departments, each with a certain degree of autonomy, specific issues can be handled by specialized personnel and managed using appropriate strategies. If, for example, environmental issues require more monitoring than trade issues, the relevant department could be managed and staffed to achieve that end.

The departmental approach dominates the alternative of stand-alone specialized organizations. All the advantages of stand-alone institutions-expertise, customized structure, and specialization-could be achieved within a department. Housing the departments within a single organization would, furthermore, preserve the enormous benefit of unified and effective dispute resolution and the ability to enter into multi-issue negotiations. ${ }^{104}$

Expanding the WTO would, of course, require an increase in the resources provided to the institution. This increase, however, would almost surely be less than that required to establish or reform stand-alone organizations. By bringing various issues within the WTO, some economies of scale could be achieved, including a single dispute resolution system, shared physical facilities, more efficient research where topics overlap, and so on.

Two important caveats must be made at this point. First, the WTO need not, and probably should not, have a monopoly on international cooperation. Suppose, for example, that environmental issues were brought into the organization. There would still be room for other, non-WTO environmental organizations to exist, including regional environmental organizations. Furthermore, tasks that simply cannot be handled within the WTO could be left with a non-WTO organization. This is what has happened in the intellectual property area. Intellectual property has been brought into the WTO through the TRIPs Agreement, but WIPO continues to exist as a separate organization. Indeed, non-WTO organizations may find their influence enhanced by the presence of a reformed WTO if the WTO departments looked to them for expertise and advice. ${ }^{105}$

WIDENER L. SYMP. J. 109, 129 (2001).

102. Even a GATT report reached this conclusion. "The GATT is not equipped to become involved in the tasks of reviewing national environmental priorities, setting environmental standards or developing global policies on the environment." GATT Report by Ambassador H. Ukawa, Chairman, Group on Environmental Measures and International Trade, to the 49th Session of the Contracting Parties, I 9, L/7402 (Feb. 2, 1994).

103. See Kelly, supra nore 101, at 129-30.

104. See Andrew L. Strauss, From GATTzilla to the Green Giant: Winning the Environmental Battle for the Soul of the World Trade Organization, 19 U. PA. J. INT'L ECON. L. 769, 803-05 (1998).

105. For example, the standards, guidelines, and recommendations of the Codex Alimentarius Commission, the International Office of Epizootics, and the Secretariat of the International Planc Protecrion 
Second, though this Article supports the inclusion of environmental issues, competition policy, intellectual property, human rights, and labor issues, it is not a call to include all of those topics in one fell swoop. As with any organization, change that is conducted too quickly may strain the system. In the short term, the WTO should adopt a departmental structure along with separate issue area negotiations in trade and intellectual property. ${ }^{106}$ It should also undertake serious negotiations about incorporating environmental issues during the Doha Round, at least inasmuch as they impact trade obligations. ${ }^{107}$ The WTO should also begin to pave the way for including competition policy and labor issues. It is inevitable that timetables for this sort of international cooperation are unreliable, so I do not advance one here. It will take time for the WTO to address legitimate non-trade concerns, and the sooner the organization begins moving in that direction, the better. ${ }^{108}$

\section{Acquiring Expertise}

One of the challenges facing a reformed WTO is ensuring that agreements and standards are prepared by qualified specialists. It has been proposed that the WTO work with other international organizations to tap into existing sources of expertise. Thus, labor standards might be taken from the ILO and, as was done in the TRIPs Agreement, intellectual property standards might be borrowed from WIPO. ${ }^{109}$ With the WTO structured as it is, working with more specialized organizations makes sense. Under the proposal advanced in this Article, however, the WTO itself would have departments within which there would be expertise in non-trade issues. Even with such in-house specialists, it may be wise to consult other organizations, but the presence of in-house expertise will improve the communication between the WTO and other institutions and allow more sophisticated judgments by the WTO when considering the adoption or modification of standards prepared by other institutions. The presence of specialists within the organization also would make it relarively easy for one department to seek the coun-

Convention are incorporated into the Sanitary and Phytosanitary Agreement and, therefore, have a much larger impact on national policymaking than would have been the case before the Uruguay Round. See Agreement on the application of Sanitary and Phytosanitary Measures, Apr. 15, 1994, art. III(1), annex A I 3, in Annex IA to the Agreement Establishing the World Trade Organization, Final ACT, supra note 29, reprinted in World Trade Organization, The Legal. Texts: The Results of the Uruguay Round of Multilateral. Trade Negotiations 59.

106. It may be preferable to sub-divide trade further into, for example, trade in services, trade in goods, and trade in agriculture. This Article does not advance a view on the question of how many departments should be created to handle the different aspects of trade.

107. The Ministerial Declaration adopted at Doha in November 2001 opened the door for discussion of environmental issues, but appears to have limited the agenda to the interaction of trade and environmental agreements. See Doha Declaration, supra note 9. There may, therefore, be only limited scope for the incorporation of environmental issues at this stage.

108. Much more could and should be said about the pace and order of incorporation, but such discussions will be left for another time.

109. See Bronckers, supra note 12 , at 49. 
sel of experts from another department. This sort of interdepartmental cooperation could be carried out less formally, more frequently, and at lower cost than cooperation between the WTO and stand-alone organizations.

Having in-house experts is important because the WTO's mission is different from that of other organizations. It must make independent judgments about the desirability of any particular standard or practice. The ILO, for example, has a great deal of expertise about labor, but less interest or expertise in trade. Because the WTO, under this Article's proposal, will be in the business of balancing trade and labor interests, it cannot rely exclusively on the ILO to evaluate labor issues. The WTO itself must have the ability to weigh the concerns felt in each area-something that more specialized organizations are not designed to do.

Some may be concerned that WTO departments would lack the autonomy of existing issue-oriented organizations. Such a concern would be misplaced for several reasons. First, the WTO should establish departments with considerable independence, allowing them to pursue the policy issues that they believe to be most important, and operating without undue control by the larger organization. Second, though the autonomy of issueoriented organizations is often important, it sometimes hampers their effectiveness. For example, the ILO can issue labor standards for the international community, but they are not binding on any state absent some form of international agreement. Even if a treaty is concluded, the obligations within that treaty may not be respected, and there are few mechanisms in place to ensure compliance. Finally, standards issued by the ILO may run afoul of commitments in other areas, such as trade. Complaints about the trade bias of the WTO express, in part, the fact that the success of the organization has made it difficult for other issues to be heard when trade issues are implicated. The autonomy of the ILO does not seem especially valuable if the interests of the ILO are consistently pushed aside by the more powerful interests of the WTO. By joining a reformed WTO, labor, along with environmental and other issues, will be pur on an even fooring with trade, and the interests of each of these groups will be balanced in a single policy setting.

\section{Trade Bias}

There is a widespread view among opponents - and many supporters-of the WTO that the institution has a trade bias which makes it difficult for other issues to receive a fair hearing. ${ }^{110}$ This is hardly surprising in an organization that has been dedicated from the beginning to trade liberalization, but it generates understandable resistance to the idea of an expansion

110. See Sara Dillon, Fuji-Kodak, the WTO, and the Death of Domestic Political Constituencies, 8 MinN. J. Global TRADE 197, 208-09 (1999); James Thuo Gathii, Re-Characterizing the Social in the Constitutionalization of the WTO: A Preliminary Analysis, 7 WIDENER L. SYMP. J. 137, 155 (2001); Patti Goldman, The Democratization of the Development of United States Trade Policy, 27 CoRNELL INT'L L.J. 631, 645 (1994). 
of WTO influence. ${ }^{111}$ The concern among those with interests in other areas is that non-trade issues will be overshadowed by the institution's commitment to trade.

The term "trade bias" can encompass many different concerns, two of which are addressed here. First is the claim that there is something inherently different about trade as compared to other issues that would prevent their coexistence in a single organization. For example, at least one commentator on competition policy argues that trade is a fundamentally adversarial process, whereas competition policy is not. ${ }^{12}$ If this is so, the argument goes, the sort of cooperation necessary to advance international competition policy goals may be inconsistent with the adversarial nature of the WTO. ${ }^{113}$

Though there are differences between trade and other issues, these differences should not be exaggerated. International cooperation always involves states pursuing their national self-interest and trying to get as much as possible in exchange for the fewest possible concessions. Because negotiated agreement requires unanimous consent, it also involves an effort to achieve a $\mathrm{Pa}$ reto-improving arrangement. ${ }^{114}$ When viewed as a forum for international cooperation, there is nothing about the WTO that inherently favors trade over other concerns. That is, it is not the institution itself that leads to a trade bias, but the individuals that populate the institution.

This brings us to the second, more serious trade bias concern-that nontrade issues will receive less than a fair hearing within the WTO structure. ${ }^{115}$ If the WTO were simply to declare that environmental issues were within its mandate and assign existing personnel within the WTO to address the topic, environmentalists would have cause for concern. ${ }^{16}$ Because the WTO is a trade institurion, it has developed expertise in the trade area. The people who work within the WTO are interested in and knowledgeable about trade rather than environmental issues, human rights, or other topics. The only way to overcome the perceived trade bias is to involve individuals with an interest in and commitment to relevant non-trade issues. On the other hand, adding, say, environmental specialists to the existing WTO might undermine the benefits of specialization. The same trade-off exists with respect to negoti-

111. See Robert Howse, From Politics to Technocracy-and Back Again: The Fate of the Multilateral Trading Regime, 96 AM. J. INT'L L. 94 (2002) (providing an insightful intellectual history of the international trading system since the Second World War).

112. See Tarullo, supra note 26 , at $493-94$.

113. 1 d.

114. One of the important benefits of expanding the role of the WTO-the ability to make transfers across issue areas-is a mechanism to make more Pareto-improving agreements available. See supra Part III.C.2.

115. See, e.g., Jeffrey L. Dunoff, Reconciling International Trade with Preservation of the Global Commons: Can we Prosper and Protect?, 49 WASH. \& LeE L. REv. 1407, 1441 n.214 (1992) ("The environmental community is understandably reluctant to see a trade institution such as the GATT adjudicate disputes between trade interests and environmental interests.").

116. To a certain extent, of course, the WTO is already involved in environmental issues. By limiting the use of trade sanctions as a mechanism to encourage environmental compliance, the WTO undermines certain environmental efforts. See GATT arts. XX(b), XX(g). 
ating rounds. At present, discussions are held among member representatives whose interest is primarily, though not exclusively, in trade. Though this may generate a trade bias, it has the advantage of providing focus for the negotiations. Adding non-trade participants might counter the trade bias, but would also undermine the cohesiveness of the process.

The departmental structure advocated by this Article offers an effective way to address the trade bias while maintaining a focused and specialized approach to trade. Trade issues that do not implicate environmental concerns, for example, could be handled by the trade department, which would not be terribly different from the current WTO structure. Similarly, environmental specialists could reach agreement on environmental issues. The same structure would exist in other departments.

The departmental structure takes advantage of the fact that a great deal can be accomplished without involving experts from more than one field. For example, any number of environmental agreements are possible without resorting to transfers that run across issue areas-indeed, most existing environmental agreements would fit this description. By structuring the organization along departmental lines, it is possible to capture the advantages of specialization that would be present in a stand-alone organization, including a more narrowly focused expertise, a deeper understanding of the relevant issues, and streamlined negotiations.

Problems that require cooperation across departments will obviously be more challenging than those that can be resolved within a single department, but that is both inevitable and desirable. Balancing, for example, a desire for improved labor rights against the risk of protectionism is both conceptually and politically difficult. ${ }^{117}$ More generally, the trade-offs involved when one has to consider more than one issue area are much more complex and controversial than those involved in a single issue area. This difficulty is unavoidable, but the incorporation of non-trade issues into the WTO at least makes it possible to address these questions, something that stand-alone organizations fail to do. As a practical matter, because the WTO is more influential than other international organizations, its preferences with respect to the appropriate balance between trade and other concerns tend to dominate. Expanding the jurisdiction of the WTO would force the trade interests of the current WTO to share the decision making process with other interests. ${ }^{118}$

117. See Howse \& MUTUA, supra note 22 , at 15.

118. It is worth noting that the bias of individuals working within particular interest areas is limited by the fact that these individuals are government officials. Though trade officials may have a pro-trade bias, they must answer to their political superiors who have a broader agenda. And though each issue area has a biased perspective, it is important to remember that domestic institutions are able to balance, for example, trade and environmental concerns, and the resulting policies can be communicared to the trade and environmental officials, greatly reducing the impact of the latter's biases. 


\section{Dispute Resolution}

Concerns about a trade bias are not, of course, limited to the negotiation of WTO obligations and the day-to-day operation of the organization. They are also present in the dispute resolution process. There is concern that WTO panels and the Appellate Body, when faced with a case that implicates nontrade issues, do not give adequate weight to these concerns. ${ }^{119}$ The incorporation of non-trade issues and the resulting access to the WTO's dispute settlement procedures would help to put these other values on an equal footing with trade. The question, then, is how to reform the dispute resolution process without sacrificing its efficacy or authority, and while ensuring that it does not systematically favor one issue area over another.

One solution would be to place dispute resolution procedures within the departments. This would imply separate tribunals for various issue areas and would resemble a system of stand-alone organizations, each with its own dispute resolution system. ${ }^{120}$ The problems with this approach are obvious. First, there would be no single forum in which disputes that implicate more than one area could be resolved. Mulriple fora would give the parties an incentive to forum shop, forcing the dispute resolution systems to generate choice of forum rules. In addition, there is no guarantee that the multiple dispute resolution units would agree on the relevant rules, so there may be power struggles among departments. As with any choice of forum problem, one would expect more than one of the competing fora to claim jurisdiction over some cases, leading to conflicting rulings and uncertainty as to the legal status of certain disputes.

Even if the jurisdictional problems were resolved, there would remain a problem of forum bias. A dispute resolution procedure designed for the environmental department, for example, would presumably select panel members from a list of individuals with an appropriate understanding of environmental issues. These individuals may not, however, have expertise in trade or other areas, leading to concerns about bias and qualification that look very much like the concerns that are currently expressed when non-trade issues represent an important part of a WTO dispute.

A better solution is to have a single dispute settlement body handle all cases, regardless of their content. A single forum eliminates the need for complicated choice of forum rules, prevents parties from pleading their cases strategically in an attempt to gain access to one forum rather than another, and makes an unbiased dispute resolution system easier to construct.

If we are to maintain a common dispute resolution system for a wide range of international claims, however, it must be structured in such a way so as to have adequate expertise to address the issues at hand, and yet not have a bias

119. See, e.g., Dunoff, supra note 115 , at 1441 n.214.

120. See, e.g., Amedeo Postiglione, A More Efficient International Law on the Environment and Setting Up an International Court for the Environment Within the United Nations, 20 ENVTL. L. 321 (1990) (calling for the establishment of an "International Court for the Environment"). 
in favor of any single area. To achieve this goal, panelists should not all be experts in the same field and the individual panelists in a case should be chosen with care. ${ }^{121}$ The pool of potential panelists would have to be expanded to include specialists in all relevant fields. In fact, the best panelists would probably have knowledge of more than one of the substantive issue areas. ${ }^{122}$ One might be concerned that broadening the expertise of the pool of panelists might reduce the expertise of panels. This need not be so because a dispute that involves only trade issues, for example can be assigned panelists that are trade experts. It is, after all, the individual panel rather than the pool of panelists that matters for any given case. In other words, the expertise of the panel can be tailored to suit the issues in dispute. Once the pool of potential panelists is selected, the actual establishment of panels would be fairly straightforward and could essentially follow existing WTO rules. ${ }^{123}$ Those rules state that the "Seçretariat shall propose nominations for the panel" from an existing list of qualified individuals. ${ }^{124}$ The parties are able to oppose a nomination, but are only supposed to do so "for compelling reasons." 125 If the parties cannot agree on the panelists within twenty days from the date of the establishment of the panel, the Director-General selects the panelists. ${ }^{126}$ These same rules would be appropriate for panel formation with an expanded WTO. Panelists that are perceived to favor one position over another could be vetoed by the parties, ensuring that a reasonably unbiased panel would be selected. ${ }^{127}$

A similar procedure could be used to appoint members of the Appellate Body. Because this is a standing body with only seven members, it is par-

121. At a minimum, the qualificarions for panelists provided in Article 8.1 of the DSU would have to be expanded to include individuals with expertise in non-trade areas.

Panels shall be composed of well-qualified governmental and/or non-governmental individuals, in-

cluding persons who have served on or presented a case to a panel, served as a representative of a

Member or of a contracting party to the GATT 1947 or as a representative to the Council or Committee of any covered agreement or its predecessor agreement, or in the Secretariat, taught or pub-

lished on international trade law or policy, or served as a senior trade policy official of a Member. DSU art. 8.1.

122. One way to partially offset the inevitable predisposition of panelists would be to consider accepting amicus briefs from relevant non-governmental organizations (NGOs). See Dunoff, supra note 115, at 1441 n.214; Georg C. Umbricht, An Amicus Curiae Brief on Amicas Curiae Briefs at the WTO, $4 \mathrm{~J}$. INT'L ECON. L. 773 (2001). The amicus brief issue implicates questions that go beyond what is discussed here, and this Article does not intend to advocate their acceptance by panels. The point is simply that if the WTO is reformed as proposed in this Article, there may be an additional reason to consider those briefs.

123. What is really important here is that the overall pool of panelists not be heavily biased in favor of a particular set of views. Just as domestic court systems accept that individual judges may have different temperaments, predispositions, and preconceptions, so must the DSU. Establishing lists of Appellate Body members that include a range of expertise and backgrounds would protect against a system of dispute resolution that systematically favors trade over environment or vice versa.

124. See DSU art. 8.6.

125. See id.

126. See id. art. 8.7 .

127. Concerns about bias could be furcher addressed by drafting a stronger and more defined set of rules with which a party could prevent a particular panelist from joining the panel. For example, each party could be permitted to block a certain number of nominations. 
ticularly important that the individuals serving on the Appellate Body be qualified and unbiased. It appears that the existing system of appointment, under which the Dispute Settlement Body (DSB) appoints members of the Appellate Body, can remain in place as the WTO extends its jurisdiction to include additional issue areas. ${ }^{28}$ Broadening the scope of issues handled by the WTO and the Appellate Body would require a less trade-focused Appellate Body. Members of the Appellate Body would tend to have somewhat more general interests, moving the Appellate Body closer to the model of appellate courts in virtually all domestic systems that allow judges to review and rule on a range of subjects.

Though it may seem self-evident, it is also worth noting that after the inclusion of non-trade issues, panels cannot interpret all obligations against a background pro-trade liberalization principle. ${ }^{129}$ Rather, agreements in nontrade areas must be interpreted on their own terms and not through a trade lens. ${ }^{130}$ Where two or more agreements are being litigated simultaneously, panels will have to resolve the issue through tools of treaty interpretation orher than a principle of trade liberalization.

None of this is intended to suggest that resolving disputes that implicate both trade and non-trade issues is an easy task. The point is that the only way for a tribunal to weigh both trade and non-trade interests without an institutional bias in favor of one or the other is to have a dispute resolution process that is common to both issue areas. Without a single authoritative dispute resolution mechanism, there is no unbiased forum for the resolution of disputes that cross issue areas and no orderly way of handling such disagreements.

\section{B. Democracy and Transparency}

In addition to whatever other challenges the WTO faces, there is no denying that it has a legitimacy problem. ${ }^{131}$ With greater power and influence have come concerns that the institution is insufficiently democratic. ${ }^{132}$ One sensible formulation of the democratic challenge to the WTO identifies

128. Recall that the DSB includes all member states, so every state will have input into the selection of Appellate Body members. The risk of an appointment that systematically disfavors a particular group of states is greatly reduced because every member is involved.

129. See, e.g., Marco C. E. J. Bronckers, The WTO Reference Paper on Telecommunications: A Model for WTO Competition Law?, in New Directions in International Economic Law: Essays in Honor of JoHN H. Jackson 371 (Marco Bronckers \& Reinhard Quick eds., 2000).

130. See Bronckers, supra note 12 , at 48.

131. See Kal Raustiala, Sovereignty and Multilateralism, 1 CHI. J. INT'L L. 401 (2000); Anne-Marie Slaughter, Building Global Democracy, 1 CHI. J. INT'L L. 223 (2000); Paul Stephan, Accountability and International Rulemaking: Rules, Rents, and Legitimacy, 17 Nw. J. INT'L L. \& BuS. 681 (1996); Robert O. Keohane \& Joseph S. Nye, Jr., Between Centralization and Fragmentation: The Club Model of Multinational Cooperation and the World Trade Organization: Problems of Democratic Legitimacy (Feb. 2001), available at http://ksgnotes l.harvard.edu/Research/wpaper.nsf/rwp/RWP01-004/\$File/rwp01_004_nye_rev1.pdf (last visiced May 1, 2004).

132. See Kelly, supra note 101, at 111 . 
three forms of democracy deficit. These are the lack of direct democratic input, the risk of regulatory capture, and adjudication by WTO tribunals. ${ }^{133}$ Each concern is addressed in turn.

\section{Direct Democratic Input}

The most obvious democracy problem at the WTO stems from the fact that the organization receives no direct democratic inpur. ${ }^{134}$ Individuals are only heard through the actions of their governments. At the W'TO, this familiar agency problem is compounded by the fact that it is not elected officials who enter into negotiations. Rather, the participants at the WTO are agents of the governments they represent.

Before discussing this issue further, it is worthwhile to note that a move toward more global governance inevitably moves some decisions further away from individual voters and democratic control. ${ }^{135}$ Even the European Union, which represents a far more advanced, sophisticated, and complete move toward international governance, faces serious concerns about its democratic deficit. ${ }^{136}$ To a certain extent, this is an inevitable consequence of growing interdependence. Just as decisions by the federal government are further removed from voters than those of local governments, decisions made by supranational organizations are further removed than national decisions. In principle, the problem could be overcome-or at least mitigated-through some form of direct election of representatives to an international legislative body. In practice, of course, it is difficult to imagine such a direct form of democracy at the international level. ${ }^{137}$

A second point to keep in mind when considering the democracy problem is that it should not be exaggerated. The problem is certainly a real one that needs to be discussed, but there remain democratic checks at the WTO. First, decisions taken and agreements reached by negotiators and other national representatives are ultimately judged by voters (in democratic states) in much the same way as they judge decisions of national authorities. Second, because the creation of "legislation" at the WTO continues to require unanimity, ${ }^{138}$ there is a deeply conservative bias embedded in the decision

133. See Atik, supra note 67 , at 455 .

134. See id. at $455-56$.

135. See id. at 454-59; Jeffery Atik, Identifying Antidemocratic Outcomes: Autbenticity, Self-Sacrifice, and International Trade, 19 U. PA. J. INT'L ECON. L. 229, 235-39 (1998); Jeffrey Dunoff, Is the World Trade Organization Fair to Developing States?, 97 AM. SOC'Y INT'L L. Proc. 153, 154 (2003); Paul Stephan, International Governance and American Democracy, 1 CHI. J. INT'L L. 237, 245-53 (2000).

136. See Renaud Dehousse, European Institutional Architecture After Amsterdam: Parliamentary System or Regulatory Structure?, 35 CoMmon MKT. L. REv. 595, 598 (1998); J. H. H. Weiler, The Transformation of Europe, 100 YALE L.J. 2403, 2466-74 (1991).

137. See Atik, supra note 135, at 249.

138. Beyond the periodic "rounds" that form the foundation of WTO rulemaking, there are some provisions for majoritarian decision making. These provisions, however, are limited in nature and, despite the existence of voting rules, typically operate, as a practical matter, through consensus. See, e.g., GATT art. XXV:5. 
making apparatus. ${ }^{139}$ States need not worry that policies will be forced upon them. To the extent that national decision makers are democratically accountable, therefore, they serve as guardians of the interests of their citizens.

It is also worth noting that the democracy problem at the WTO should not be confused with imperfections in domestic democracies. Though we may wish for more democracy in our domestic politics, we must accept that domestic institutions are imperfect. Identifying flaws in the domestic system does not lead to any particular policy conclusion with respect to international organizations. Critics at times seem to suggest that the WTO must not only reach a level of democracy rivaling what we see in domestic politics, but that imperfectly democratic national policymaking is itself a problem for the WTO. For example, at least one commentator includes in his discussion of the WTO's "democracy deficit" the criticism that American participation in the formation of the WTO was approved with "fast track" authority. ${ }^{140}$ It is claimed that because fast track is not "a more democratic process than ordinary Congressional deliberations" 141 the decision to join the WTO is "doubtful from a democratic standpoint."142 Surely this argument cannot be taken as a serious criticism of democracy at the WTO. For the foreseeable future, international institutions cannot hope to achieve a level of democracy that rivals that of democratic national regimes. The most that can be hoped, it seems, is that national policies relevant to the organization are made within a democratic polity. To insist that these decisions be made within the most democratic corners of that polity is to demand too much. It is neither fair nor constructive to undermine support for international cooperation based on such unrealistic expectations.

Finally, when discussing democracy issues at the WTO, the organization should be compared to the available alternatives rather than to some idealized vision of democracy. Even democratic states suffer from serious problems related to their decision making. The most salient of these is the influence of interest groups. Some claim that this problem is especially acute in the foreign relations sphere, ${ }^{143}$ and others suggest that it calls into ques-

139. Although it is at times convenient to describe the WTO as a "government" or as a "constitution," the presence of the consensus rule probably makes it more accurate to refer to it as a "contract." Furthermore, there are no coercive mechanisms within the organization. Compliance with obligations and DSB rulings is enforced only through policical or reputational mechanisms. Even the sancrions provided for in the event of a refusal to bring one's actions into compliance with a ruling of the DSB operate only prospectively. They are intended neither to be punitive nor to make compliance unavoidable. See DSU art. 22.4 ("The level of the suspension of concessions or other obligations authorized by the DSB shall be equivalent to the level of the nullification or impairment."); Mary Foorer, The Role of Consensus in GATT/WTO Decision-Making, 17 Nw. J. INT'L L. \& Bus. 653 (1996).

140. See Atik, supra note 135, at 237. Fast track authority, renamed Trade Promotion Authority in 2002, allows the executive to negotiate trade agreements which Congress must either approve or reject without amendment. See Gary G. Yerkey, White House Set to Press Congress on Export Control Legislation This Fall, 19 Int'l TRade ReP. (BNA) No. 32, 1374 (Aug. 8, 2002).

141. Atik, supra note 67 , at 460 .

142. Id.

143. See McGinnis \& Movsesian, supra note 23, at 556-58. 
tion international cooperation in general. ${ }^{144}$ The public choice problem remains, however, whether the WTO is enlarged to incorporate environmental, human rights, and labor issues, whether those issues are left to other international organizations, or whether cooperation in those areas is done only through ad hoc negotiations. The inclusion of non-trade issues within the WTO would not make the problem any more serious.

Furthermore, it is an illusion to think that weakening or eliminating the WTO or other international institutions leaves the world more democratic. Where international organizations are weak or nonexistent, the international sphere is marked not by democracy but by anarchy. The high barriers to trade that existed prior to the establishment of the GATT were only "democratic" in the sense that they were put in place by national governments. There is no serious doubt that those policies were harmful and contrary to what a democratic polity (meaning one free of public choice problems) would have chosen. The adoption of the GATT led to an opening of trade and an increase in welfare that can be considered more democratic than what existed before because it delivered a higher quality of life and because it allowed the interests of exporters to be taken into account alongside those of import-competing industries.

At the end of the day, we have to accept that an agency problem will remain in any forum for international cooperation. The best we can do is try to reduce its impact. One frequently proposed strategy is to increase the transparency and openness of the institution. This solution has been discussed elsewhere and a full discussion would take us far afield. ${ }^{145}$ It is enough to note that a great deal of WTO activity is done in secrecy, closed off even from other international organizations. ${ }^{146}$ The most obvious solution is to make more of the institution's processes and documents available (e.g., pleadings in cases before dispute panels), so that the actions of negotiators and bureaucrats can be monitored more closely by all interested parties.

Although the reforms proposed in this Article cannot eliminate the agency problem between WTO participants and individuals, they do ameliorate it. One of the concerns raised about WTO participants is that they are insiders with a common set of values and priorities that differ from those of their governments. ${ }^{147}$ Bringing other issues into the WTO means bringing in individuals with different sets of values. A wider range of views on, for example, the relationship of trade and environmental issues, or the appropriate balance between sanitary and phytosanitary measures and trade liberalization, will exist within the organization. The departmental structure

144. See Paul Stephan, Regulatory Cooperation and Competition: The Search for Virtue, in TransatlantiC Regulatory Cooperation-Legal. Problems and Political Prospects 167 (George A. Bermann et al. eds., 2000).

145. See Barfield, supra note 3, at 413; Howse, supra note 111, at 107; McGinnis \& Movsesian, supra note 23 , at 576 .

146. See Howse \& Mutua, supra note 22, at 14 .

147. See Howse, supra note 111 , at 98-99 (referring to the "insider network" at the WTO). 
will separate the various issue areas, but the heterogeneity of perspectives within the organization will nevertheless be increased. ${ }^{148}$

The proposal advanced in this Article also advances a form of democracy by facilitating international cooperation. Domestic policymakers dealing with international issues are responsible to only some of the individuals that are affected by the policies-their own constituents. For example, if a national government adopts weak environmental policies because it knows that much of the harm from those policies will be felt by foreigners, it may be responding to the wishes of its constituents. There is, however, no voice for affected individuals outside the country. International cooperation, when successful, allows states to exchange promises through which each state can influence the conduct of the others-giving their constituents at least some voice in the policies of other states. If no effective mechanism for cooperation is established, the policies adopted by states will often be ineffective, ${ }^{149}$ undesirable, ${ }^{150}$ or both. Though international cooperation does not give all affected individuals equal voice, and international institutions are at best controlled indirectly by voters, it is often an improvement over unilateral polices that ignore the interests of foreign parties. Bringing additional issues into the WTO expands the scope for international cooperation, thereby making it easier for states to enter into consensual agreements that serve the interests of citizens in all affected countries.

Having said all of the above, there is no denying that there remains a democracy problem at the WTO that will not go away with the adoption of this Article's proposal. In fact, it may become more salient because the organization will have greater reach. ${ }^{151}$ On the other hand, the same democracy critique affects virtually all forms of international cooperation. ${ }^{152}$ The

148. A related argument is that dealing with issues at the international level may reduce the power of concentrated domestic interest groups. See Kal Raustiala, Retbinking the Sovereignty Debate in International Economic Law, 6 J. INT'L ECON. L. 841, 864-67 (2003).

149. Cf. Michael Allen, As Dot-Coms Go Bust in U.S. Bermuda Hosts an Odd Little Boomlet, Wall ST. J., Jan. 8, 2001, at $A 1$ (discussing the use of tax havens to avoid full tax jurisdictions).

150. See Andrew T. Guzman, Choice of Law: New Foundations, 90 GEo. L.J. 883, 904-06 (2002) (explaining how unilateral policies can diverge from globally optimal policies).

151. The democracy problem would probably be at least as significant if inrernational cooperation were carried out through specialized issue-oriented institutions such as the ILO or an international environmental organization.

152. One could, of course, conclude that international cooperation should be discouraged and avoided if the agency problems associated with it are thought to be sufficiently serious. See Stephan, supra note 131; Stephan, supra note 144. I have replied to this critique of international cooperation in some detail in past writing. See Andrew T. Guzman, Public Choice and International Regulatory Competition, 90 GEO. L.J. 971, 977-80 (2002). Absent some specific reason to shy away in a particular case, there are strong reasons to seek rather than shrink from cooperation. First, the internationalization of virtually every aspect of life generates many more cross-border interactions and many more instances in which purely domestic government decisions cannot adequately address the needs of affected individuals. It would be stunning if the optimal level of international cooperation did not increase along with these changes. Second, it is easy to point to instances of cooperation that have generated a net increase in welfare, including the trade liberalization that has occurred through the GATT/WTO system. A systematic turning away from cooperarion would foreclose fucure efforts that could have similarly large payoffs. Finally, there is no guarantee that public choice problems are smaller in the domestic context than in the international context. Inter- 
problem should be addressed and considered, but it is important to note that the problem is not at root the product of the WTO's structure. The problem is inherent in a system of interdependent nation states.

\section{Regulatory Capture}

Critics of an expanded WTO have also expressed a related concern regarding regulatory capture. ${ }^{153}$ Among their worries about an expanded WTO is the possibility that concentrated interest groups would gain great influence over such an organization and would be able to influence policy to suit their own private objectives. ${ }^{154}$ These are certainly valid concerns, and the WTO should remain attentive to this possibility, but the proposal advanced here simply does not leave the organization vulnerable to this sort of capture. Because no authority would be delegated to administrative bodies, the organization would have no independent regulatory decision making authority and could not override the interests of individual states. As is true with the WTO today, commitments would be the result of negotiated treaty text, approved unanimously by the member states. Even the drafting of the legal obligations would be subject to intense negotiation, as is currently the case. The rules themselves are even approved by states, so there is no risk that some imagined WTO bureaucrats could influence the process by controlling the drafting of proposed rules or through some other process. Though there remains the above discussed risk of a democracy deficit, the absence of decision making agencies avoids the problem of regulatory capture. It is simply not possible to capture regulators and a regulatory apparatus that do not exist. Because there is no separate regulatory authority housed within the WTO, the proposal represents a form of collective governance, not supranational government.

\section{Adjudicators of International Law}

The previous sections have discussed the democracy problem with reference to negotiators and technocrats at the WTO. There is a different but equally important problem at the dispute resolution phase. WTO panels and the Appellate Body interpret WTO agreements, and through these interpretations, affect member obligations. Though the text of the DSU suggests otherwise, ${ }^{155}$ WTO panels and the Appellate Body, through their

national negotiation can, at times, reduce the influence of certain interest groups and make sound domestic decisions more likely. International trade is once again a good example. The ability to enter into trading agreements causes export interests to lobby for liberalization-countering the impact of import competing interests. Ultimately the impact of public choice on international cooperation must be evaluated on a case-by-case basis and, absent strong evidence that cooperation will be harmful in a given context an isolationist approach is unwise.

153. See, e.g., McGinnis \& Movsesian, supra note 23, at 556-58.

154. Id. at 556 ("A commission or agency charged with international regulation would be particularly prone to capture by protectionist interest groups.")

155. See DSU art. 3.2 ("Recommendations and rulings of the DSB cannot add to or diminish the 
unelected and essentially unaccountable panelists, make law. Unlike judicial actions within democracies, there is no democratically chosen legislature capable of checking the authority of the panels. ${ }^{156}$ Among the questions this raises is the proper role of panels in interpreting WTO obligations. Specifically, should they restrict their interpretation of WTO obligations to the text of the relevant agreements, or should they also consider other aspects of international law or international norms? This question is the subject of debate among international trade scholars. Under the status quo, the one thing that is clear is that the answer to the question must eventually come from the Appellate Body. Bringing non-trade topics into the WTO would offer the more attractive alternative of having negotiators address this question.

On one side of this debate are commentators who have suggested that WTO panels should take into account at least some non-trade values that are external to the WTO agreements. ${ }^{157}$ For example, Robert Howse and Makau Mutua argue that trade law is accountable to human rights law. ${ }^{158}$ They point out that, to the extent human rights obligations are preemptory norms, these obligations trump trade law treaties. ${ }^{159}$ They then suggest that panels should permit the use of trade sanctions against violations of such preemptory norms. Howse and Mutua also make the more controversial claim that interpretation of WTO agreements should be carried out with reference to the evolving norms of international law. They argue that interpretation of Article XX of the GATT, ${ }^{160}$ which lists the general exceptions to GATT obligations, would "have to be considered in light of relevant rules of international law, including international agreements on human rights." ${ }^{61} \mathrm{Fi}$ nally, they make a third, still more controversial, assertion. They point out that under Article 103, the U.N. Charter takes precedence over conflicting

rights and obligations provided in the covered agreements.").

156. There is, at least in principle, some ability to check panel rulings through a refusal by the DSB to adopt the ruling, which requires: unanimity, DSU art. 16.4; a waiver, GATT art. XXV.5 and FINAL ACT art. IX:3; an amendment to the relevant agreement, GATT art. XXX; or the adoption of an interpretation of the WTO agreements, FINAL ACT art. IX:3. Each of these procedures, however, is cumbersome, unwieldy, and virtually impossible to use in most cases.

157. See PAUWELyN, supra note 38, 456-72; Howse, supra note 18, at 134-35; HowSE \& MUTUA, supra note 22; Howse \& Nicolaïdis, supra note 38; Patricia Stirling, The Use of Trade Sanctions as an Enforcement Mechanism for Basic Human Rights: A Proposal for Addition to the World Trade Organization, 11 AM. J. INT'L L. 7, 40-45 (1996).

158. See Howse \& MUTUA, supra note 22, at 7-8 ("Human righrs, to the extent they are obligations erga omnes, or have the status of custom, or of general principles, will normally prevail over specific conflicting provisions of treaties such as trade agreements.").

159. The question of whether particular human rights norms qualify as peremptory norms is complex and controversial. This Article does not attempt to make any such classification.

160. GATT art. XX ("[N]othing in this Agreement shall be construed to prevent the adoption or enforcement by any contracting party of measures: (a) necessary to prorect public morals; (b) necessary to prorect human, animal or plant life or health; ... (d) necessary to secure compliance with laws or regulations ....").

161. HOWse \& MUTUA, supra note 22, at 12. 
obligations, including treaty obligations, ${ }^{162}$ and argue that it places obligations on member states to promote and protect human rights. From these two premises, they conclude that in the event of a conflict between a human rights obligation and a WTO obligation, the former prevails. ${ }^{163}$

On the other side of the debate are commentators who believe WTO panels should only apply WTO law. ${ }^{164}$ Although there is agreement that customary international law is relevant to the way in which the Appellate Body interprets WTO texts, Joel Trachtman emphasizes that it is the customary rules of interpretation that are relevant, not substantive rules of customary international law. ${ }^{165}$ Proponents of a less expansive jurisdictional reach for panels also refer to the text of the DSU, which indicates in several places that panels should only look to WTO law. For example, Article 3 of the DSU states that "the DSB cannot add to or diminish the rights and obligations provided in the covered agreements." 166 Together with other provisions in the DSU, this language suggests that the members intended WTO law to be the exclusive source of legal authority used by the panels. ${ }^{167}$

From a policy perspective, more aggressive forays into non-trade topics by panels would further threaten the legitimacy of the WTO dispute settlement system. Though panels inevitably "make law" in a meaningful sense, to the extent their decisions tend toward policymaking rather than interpretation, they risk overstepping their institutional role. This is especially dangerous with respect to the appropriate trade-offs between trade and, for example, the environment or human rights, because there is virtually no guidance within the WTO agreements. Actions of this sort threaten to undermine the legitimacy of the dispute resolution system. ${ }^{168}$ Panels represent the least democratic component of the WTO, an institution already criticized for its anti-democratic features. ${ }^{169}$

162. See $i d$. at 14 ("It is clear here that a treaty-even one of universal application-would be overridden by the UN Charter in the event of a conflict.").

163. Id. " Thus it would appear that in the event of a conflict between a human rights obligation, particularly one that is universally recognized, and a commitment ensuing from international treaty law, the former prevails or the latrer must be interpreted to be consistent with the former.").

164. See Dunoff, supra note 20 , at 754 .

165. See Trachtman, supra note 81, at 343; DSU art. 3.2; Vienna Convention of the Law of Treaties, art. 31.3(c), May 23, 1969, 1155 U.N.T.S. 331 (1969).

166. DSU art. 3.2.

167. Other relevant provisions include additional language in Article 3, which states that dispute resolution "serves to preserve the rights and obligations of Members under the covered agreements, and to clarify the provisions of those agreements." DSU art. 3. The standard terms of reference for panels, provided in Article 7, instruct panels "[t]o examine, in the light of the relevant provisions in (name of the covered agreement(s) cited by the parties to the dispute), the matrer referred to the DSB." DSU art. 7.1. According to Article 11, the function of a panel is to "assist the DSB in discharging its responsibilities under this Understanding and the covered agreements." DSU art. 11. Finally, also in Article 11, it is stated that a panel should assess the "applicability of and conformity with the relevant covered agreements." Id.

168. See Dunoff, supra note 20 , at 756.

169. See supra Part IV.B.1. 
In any event, the main problem is not one of a direct conflict between customary international law and the WTO. Rather, the problem is how to deal with the indirect conflict between trade obligations and efforts to sanction violations of international law. Put simply, the violation of a principle of customary international law does not, by itself, justify the imposition of sanctions in violation of other agreements. ${ }^{170}$ Whether a trade sanction, which would otherwise be a violation of WTO commitments, is permitted in response to a violation of international law must be answered through the WTO agreements. ${ }^{171}$ This means that exceptions to WTO obligations based on, for example, human rights violations, require interpretation of Article $\mathrm{XX}$ of the GATT such that the trade sanctions put in place are considered "necessary to protect human, animal or plant life or health" 172 or "necessary to protect public morals." 173 Though such an interpretation is possible, it is not the only available interpretation, even if one accepts that the Appellate Body should take customary law into account. ${ }^{174}$

The reforms proposed in this Article will not resolve the debate regarding the appropriate tools of interpretation for WTO panels or other international adjudicatory bodies. The merit of the proposal in this context is that it puts control over this question where it belongs-in the hands of negotiators rather than the Appellate Body. Bringing more non-trade issues into the WTO allows member states to balance the priorities of trade against those of other interests. Bringing, for example, environmental issues within the WTO would allow states to agree on which existing environmental commitments are subject to WTO dispute resolution and which are not. Negotiated agreements would also provide guidance to future panelists regarding the interplay of environmental and trade obligations. ${ }^{175}$ Presently, the WTO provides reasonably specific guidelines regarding the circumstances in which exceptions to WTO obligations are permitted, and it provides limits on the use of such exceptions. ${ }^{176}$ If there are to be exceptions to trade obligations for envi-

170. Cf. Alvarez, supra note 53 , at 6 (pointing out that human rights obligations do not generally prevail over trade obligations).

171. The same conclusion may be reached through an S.S. Lotus style of argument. See The S.S. Lotus (Fr. v. Turk.), 1927 P.C.I.J. (ser. A) No. 10 (Sept. 27). As discussed in the Lotus case, a state is free to impose any rules it chooses within its jurisdiction, limited only by the prohibitions of international law. In particular, there is no affirmative obligation under international law to address human rights violations through the use of trade sanctions. Under customary law a state is free to trade with violators of human rights under whatever conditions it desires.

172. GATT art. XX:1(b).

173. GATT art, XX:1(a).

174. Gary Sampson, a former director of the GATT and the WTO, has commented, "[i]n the long term, policy choices as important as the legitimacy of the unilateral application of trade measures to enforce domestic societal preferences extraterritorially should not be left to litigation ..... These should be the subject of policy debates with the participation of representatives from all WTO members." GARY P. Sampson, Trade, Environment, and the WTO: The Post-Seattle Agenda 111 (2000).

175. See Alvarez, supra note 53, at 4 n.16 ("[T]he status of WTO agreements vis-à-vis particular human rights (or environmental) conventions may best be clarified through explicit provision.").

176. See, e.g., ANTI-Dumping AGreement art. IX(3) ("The amount of the anti-dumping duty shall not exceed the margin of dumping."). 
ronmental and human rights issues, states must agree on the scope of the exceptions and conditions under which those exceptions are triggered. If those decisions are placed in the hands of national representatives, the compromises reached will be based on the consent of member states rather than the decisions of unelected and unaccountable panels and appellate panels. Furthermore, where there is particular concern that the Apellate Body may overstep its bounds or create unintended obligations, the states can simply leave the matter beyond the reach of the dispute resolution system. ${ }^{177}$

Perhaps the greatest benefit of a negotiated incorporation of non-trade issues is that it provides legitimacy for the process. WTO dispute settlement procedures, though strong when compared to other international institutions, do not enjoy the stability and resilience of domestic courts in the United States or other advanced democracies. An attempt to expand the reach of panels to incorporate human rights, environmental law, or other issues without the explicit consent of member states would bring criticism from many quarters. Whether the WTO could withstand such attacks is uncertain. A failed attempt to increase the role of human rights values through the DSU might weaken the entire institution-perhaps even causing its collapse. ${ }^{178}$ Given that there is no consensus within the WTO or elsewhere about the appropriate interplay of trade and non-trade values, failure seems likely.

In contrast to the risks of a failed attempt by panels to become more activist, attempts to incorporate issues through negotiated agreements are relatively safe. In the ongoing Doha Round, for example, if no agreement can be reached on environmental issues, those issues can be put aside while negotiators focus on other areas. If the round is completed without significant progress on the environment, the WTO will very likely remain a strong and vital institution that can return to the environmental question at another time.

\section{Sovereignty Concerns}

Any expansion of global governance must confront concerns about its impact on national sovereignty. ${ }^{179}$ The sovereignty issue is related to both the level of political support for the institution and concerns about democracy. ${ }^{180}$ Once again, these concerns stem in part from the remarkable success of the WTO. Sovereignty issues arise because the WTO has succeeded in limiting the policy options of national governments. ${ }^{181}$ As Jeffrey Dunoff has pointed

177. Among other advantages, this ensures that concerns about the dispute resolution process will not prevent cross-issue area agreements from being reached.

178. Cf. Alvarez, supra note 53, at 14-16

179. See Atik, supra note 135 , at 229-30.

180. See McGinnis \& Movsesian, supra note 23.

181. For example, the WTO agreements demand that foreign goods receive national treatment. GATT art. III. They also forbid the imposition of anti-dumping measures except as permitted within those agreements. GATT art. VI; ANTI-DUMPING AgREEmENT art. 1. In addition, they ban the use of quantitative restrictions (subject to exceptions). GATT art. XI:1. 
out, the goals of advancing globalization, enhancing democracy, and preserving national sovereignty are incompatible. ${ }^{182}$ Though there is no coercive enforcement mechanism within the organization beyond the retaliation provisions of the DSU, the WTO seeks to affect state behavior, and its dispute resolution system is designed to limit the ability of states to violate their obligations. In this sense, the WTO system may be described as an authority above that of national law. ${ }^{183}$ Whether the existence of such an aurhority should lead to serious sovereignty concerns is another question.

Sovereignty is a difficult topic to discuss, given that there is no clear definition of national sovereignty that can be applied to today's world. ${ }^{184}$ It is certainly not the case (and perhaps never was) that states have complete and exclusive control over everything that takes place within their borders. ${ }^{185}$ For example, both the United States and the European Union enforce their antitrust laws extraterritorially, applying their own laws to conduct that takes place abroad. ${ }^{186}$ Nor is it the case that states refuse to cede control over domestic policy issues. The WTO exists, after all, because states sought to bind themselves collectively to certain domestic policies and practices. The remarkable cooperation among states within the European Union is another example suggesting that states are willing to cede sovereignty under the right circumstances. Sovereignty, then, involves a balance between a state's desire for autonomy and its need to forge relationships and make commitments with other states.

The sovereignty question at the WTO can be viewed through the lens of contract. Domestic legal systems allow individuals to make binding agreements. These contracts limit the furure actions of each party, but we do not criticize them as infringements on individual autonomy. In fact, we view them as tools to further individual autonomy, because they allow individuals to advance their interests more effectively than would be possible in a world without binding contracts. International agreements can be viewed as contracts among sovereign states. Like domestic contracts, they restrict (or seek to restrict) future behavior, but, like contracts, they should be viewed as serving rather than undermining the interests of states.

Since the proposal advanced in this Article does not challenge the unanimity requirement of the WTO, the organization remains more of an international contract than an international legislature. As such, it is much less of a threat to sovereignty than some critics claim. As long as every country has a veto over agreements, the WTO, in essence, represents a multilateral con-

182. See Jeffrey L. Dunoff, Mission Impossible: Resolving the WTO's Trilemma, 8 (Jan. 13, 2003), available at htcp://www.law.berkeley.edu/faculty/ddcaron/Public_Website/Courses/International\%20Law/Documents/ 2003-01\%20UC\%20Trade\%20Conf/Dunoff_WTO_Trilemma.pdf (last visited May 1, 2004).

183. See Atik, supra note 67 , at 452 .

184. See Raustiala, supra note 131 , at 417.

185. This point has been made in STEPHEN D. KRASNER, SOVEREIGNTY: Organized HypoCrisY 19-25 (1999).

186. See Guzman, supra note 150 , at 911 . 
tract and is no more of an intrusion on sovereignty than any other multilateral treaty.

Indeed, bringing negotiations under a single umbrella organization that includes a coherent and uniform dispute resolution procedure might actually protect national sovereignty. First, providing a forum in which states can reach, for example, environmental agreements would reduce pressures to impose standards unilaterally. Unilateral approaches are likely to be more violative of national sovereignty because they seek to compel other states, which have no influence over the unilateral policy, to adopt certain behaviors. Second, arguments have been advanced that sovereignty is, in fact, not compromised by internationalization, and that international institutions give states the ability to regain control over policies and outcomes they care about. "[T] $]$ he United States can better promote economic growth, prosperity, and job creation through international cooperation, specifically the WTO, than it can acting alone .... United States sovereignty is not diminished by such participation." 187

There remains at least one significant threat to our current notions of sovereignty that should concern proponents and critics of the WTO alike: the rule-making power of WTO panels and the Appellate Body. The WTO agreements inevitably have gaps, and, because unforeseen issues arise, panels often find themselves making new law. This happens in domestic common law systems, of course, but in those systems the legislature may step in and override a judicial decision, providing a democratic check on the courts. At the WTO, however, the "legislature" acts through unanimity, making it very difficult (though not impossible) to change the rules laid down through the dispute settlement system. It is possible, therefore, that states will face obligations that are shaped by panels without the consent of all, or even a significant number of members.

There is no complete solution to this sovereignty problem, but steps can be taken to reduce its impact. First, panels and the Appellate Body should be encouraged to remain as faithful as possible to the text of the WTO agreements. The text may then provide a constraint on the activism of panel members. Second, the fact that panel decisions do not, strictly speaking, create binding precedent should not be forgotren. ${ }^{188}$ If a panel creates a rule that is inconsistent with the intent of WTO members, future panels have the authority to disagree. ${ }^{189}$ Third, panels should resist the temptation to import customary international law or other international norms into their jurisprudence in the form of binding obligations. Though WTO panels are sometimes encouraged to consider these international norms in their decisions, it

187. Judith H. Bello, National Sovereignty and Transnational Problem Solving, 18 Cardozo L. REv. 1027, 1029-30 (1996).

188. See David Palmeter \& Petros C. Mavroidis, The WTO Legal System: Sources of Law, 92 AM. J. IN'T'L L. 398, 400 (1998).

189. Similarly, the Appellate Body can revisit issues it has decided. 
must be remembered that these non-WTO rules have not been incorporated into the treaty by the members of the organization. ${ }^{190}$ It should be left to the members to determine whether such international legal rules should be incorporated into the set of obligations that are adjudicated at the WTO. Finally, more creative solutions should also be considered. For example, Claude Barfield has suggested that a specified minority of WTO members (he proposes one-third of members accounting for at least one-quarter of trade among members) should be able to block a panel decision. ${ }^{191}$ A blocked ruling would impose no obligation on the losing party and would not have any legal authority. ${ }^{192}$ At the very least, this approach would prevent widely unpopular rules from becoming part of the WTO's jurisprudence. It also may help identify areas where future negotiations should occur.

In the end, it is important to recognize that traditional notions of national sovereignty are being eroded by globalization itself, not by international institutions. Faced with this loss of control, it is not clear what states will do. They can continue to rely on domestic institutions and simply accept the consequences of being unable to regulate certain activities effectively-a strategy that becomes less effective with each passing year-or they can work toward well-functioning international institutions that are as effective as possible, and as democratic as we are willing to make them.

\section{CONCLUSion}

The WTO is at a crossroads. Its current status as the most effecrive and reliable of international institutions is not sustainable if the organization retains its trade focus. It is not enough for the WTO to simply address the non-trade topics as potential trade barriers that must be regulated. Without reform, the WTO will face continued challenges to its legitimacy and criticism for its trade bias. These critiques are powerful because they are correct.

To date, the organization has struck a balance between trade and nontrade values such as the environment or human rights, but this balance is the product of the particular institutional structure of the organization rather than a collective decision of its members. The relationship between, for example, environmental issues and trade finds minimal support in Article XX of the GATT. The real driving force behind the WTO's approach to the problem has been the dispute resolution system. At no point have member states explicitly sought to frame the tradeoff between environmental values and trade values. Furthermore, a serious attempr to consider such a tradeoff

190. See Barfield, supra note 3 , at 410 .

191. See id. at 411-12. In principle, the current provisions of the WTO Agreement allow threequarters of members to adopt an interpretation of the relevant agreement, which could serve to overrule a panel ruling. FINAL ACT art. IX(2).

192. See Barfield, supra note 3, at 412 . This Article takes no position on whether this suggestion is desirable. The point is simply that such approaches should be considered as potential solutions to the problem of panel-made rules. 
cannot take place in the existing system of international cooperation. No organization other than the WTO has the ability to manage the trading system, and the WTO lacks the expertise and the will to study and properly evaluate non-trade issues. The WTO is also hampered by the fact that environmental groups and organizations are suspicious of the institution and believe that its decisions reflect a bias in favor of trade values to the detriment of non-trade values. The same problems are present with respect to labor, human rights, and competition policy.

From where it is now, the WTO can do one of two things. It can try to restrict itself to a narrower set of trade issues in the hope that its impact on important non-trade issues will be reduced to a manageable level. It is not clear exactly how such a contraction would proceed, but one approach might include a policy of giving certain non-WTO laws and norms, such as those regarding human rights, precedence over WTO law. A contraction of this sort is problematic because it does not generate a political agreement about how to balance the competing trade and non-trade values. Instead, it simply reduces the importance of trade values. Even if it represents a move in the right direction-something we cannot know without a prior understanding of how these interests should be balanced against one another-it will not generate a political discussion about these competing values, let alone an agreement on them. Furthermore, a contraction of the WTO's influence may not successfully relieve the political strains on the organization and the world trading system. A restricted WTO would remain a trade organization with a bias toward trade values and would continue to impact non-trade issues. The legitimacy problem would remain.

The alternative strategy is to address the basic tensions that are straining the WTO system. Conflict between trade and non-trade values is inevitable in today's world, making it impossible to keep trade isolated from orher policy concerns. Any sensible attempt to resolve these conflicts must include both trade and non-trade interests at the bargaining table. The WTO offers a promising place to undertake such negotiations because it has an established set of procedures and a history of organizing such international discussions. To be effective, however, the WTO must be reformed. First, the negotiations cannot be carried out in a forum and among negotiators who are perceived to favor trade values over other concerns. The talks themselves must include specialists from the relevant non-trade issue areas in addition to trade specialists. Second, simply establishing rules for the interaction of trade and non-trade issues will not resolve the problem. What is needed is an international organization that can handle the day-to-day management of these issues. Again, the WTO has many of the features one would like in such an organization, but cannot fulfill that role as long as it is merely a trade institution.

The reforms proposed in this Article would keep much of the structure of the WTO intact, but would create separate departments for each of the issue areas that come within the organization. These departments would be autono- 
mous from one another and would be authorized to hold their own Departmental Rounds of negotiation. In this way, the departments could address matters of cooperation within their issue areas at a relatively low cost and would retain the advantage of specialization. The departments, however, would not be able to balance competing trade and non-trade values. This would require negotiation across departmental lines. The Mega-Rounds would provide states with the opportunity to manage the relationship between, for example, trade and the environment, or trade and human rights. The resulting agreements would enjoy greater legitimacy because they would reflect the consent of states and because several different interests (e.g., trade, environment, labor, comperition, and human rights) would be represented. Finally, the existing dispute resolution system of the WTO-reformed to include more than just trade specialists-would remain in place to provide effective enforcement and interpretation of the resulting agreements.

The proposal as presented is unabashedly forward-looking and normative. Adoption of the entire package would be a big step for, and a radical change to, the organization. As such, one would have to rate the prospects of it happening as modest. Other more modest reforms are possible and could take place in the short term. Furthermore, it would be possible to incorporate additional topics more easily if it were done gradually. Of course, there would be opposition to such incorporation, and some form of compensatory concessions may be needed. More difficult, but still plausible, would be the establishment of a departmental structure. Departmental negotiations, in particular, could be carried out using essentially the existing negotiation procedures. ${ }^{193}$

Perhaps the most important point to make is that the WTO no longer has the luxury of ignoring non-trade issues, thus some change is needed. The GATT/WTO system has never been exclusively about trade, and no effective trading system could be so exclusive. ${ }^{194}$ Calls for a retrenchment to such a state are impractical.

As it stands, the current system has substantive rules on intellectual property, health and safety, environmental regulation, and more. In other areas, the fact that the WTO does not address the subject amounts to a decision that there will be no linkage between trade and those non-trade issues. It may be that the WTO rules on non-trade issues are correct and the decision to avoid linkages in other areas is also correct, but it would be quite surprising if this were the case. How, after all, could we hope to have achieved sensible policies when there has been no sustained political discussion of the relationship among these topics and there remains no forum in which to have that discussion?

193. Article III of the Final Act provides that the WTO is to provide a forum for negotiation. FinaL ACT art. III. The Ministerial could, under Article III, launch a Departmental Round by launching a Round with a narrow agenda, limited to a particular department.

194. See supra text accompanying note 14 . 
There is no doubt that negotiation across issue areas is difficult, and neither this proposal nor any other would eliminate that difficulty. The approach outlined in this Article, however, provides both a forum for such negotiations and a suggestion for an institution to make the resulting agreements effective. At present, such a forum does not exist. Though negotiations among states are imperfect, they are the only mechanism we have to address the important tradeoffs between trade and non-trade values. 
HeinOnline -- 45 Harv. Int'l L.J. 3522004 